\title{
LA ORGANIZACIÓN DE LOS MONASTERIOS HISPANOS EN LA ALTA EDAD MEDIA (SS. IX-X): LOS ESPACIOS DE LA 'ALDEA ESPIRITUAL'
}

\section{ARTEMIO MANUEL MARTÍNEZ TEJERA}

UDC: $27-788(365)$ "o8/o9" 726.71(365)"08/09"

Preliminary communication

Manuscript received: 27. 10. 2016.

Revised manuscript accepted: 28. 02. 2017.

DOI: 10.1484/J.HAM.5.113715
A. M. Martínez Tejera

Universidad Autonoma de Madrid (UAM)

Escuela de Doctorado

Avda. Pablo Iglesias no 82, Portal 1, 4o B 28521

Rivas Vaciamadrid (Madrid), España

artemio.martinez@uam.es

Although it can seem paradoxical, our knowledge on the Hispanic monastic phenomenon in the Late Antiquity surpass to which we have for the High Middle Ages. In the case of the written sources, the superiority is unquestionable, because for centuries VIII-X we lack testimonies like offered by San Fructuoso or San Isidoro in century VII, authors of two visions very different from the monastic life that were reflected in two monastics regulae. Respect to the space in which the monastic life was developed in Hispania, Archaeology has contributed very little to already known by the sources; and these, which seems to indicate is that during centuries IX-X in the Hispanic monastic space still was anarchic, difficult to restrict in typologies. So that personages like San Genadio, bishop of Asturica Augusta or San Rosendo, bishop of Dumio, two abbot-bishops, will be who now inform into the guidelines of habitability (infrastructure and organization) of the Hispanic High Middle Ages monastic space to us.

Keywords: Peninsula Iberian, monastic life, san Fructuoso, san Isidoro, Monasticism, abbot-bishops, san Genadio of Augusta, san Rosendo of Dumio

\section{$1^{\circ}$ ALGUNAS CONSIDERACIONES (Y NO SOLO TERMINOLÓGICAS) SOBRE EL MONASTERIO HISPANO ALTOMEDIEVAL}

Hace ya una década que llegamos a la conclusión de que hasta el último cuarto del s. VI en Hispania predominaron los 'monasterios' sobre los 'cenobios'; de que, al menos en la Península Ibérica y durante la Antigüedad Tardía (ss. V-VII), los términos monasterium y coenobium ni reflejaron una misma organización espiritual ni un mismo tipo de hábitat ${ }^{1}$. Unos y otros, monasterios y cenobios, quedaron perfectamente definidos en el s. VII por San Isidoro de Sevilla en sus De Origine ${ }^{2}$ : el coenobium como el habitáculo de muchas personas que vivían en común, el espacio destinado a un tipo de monje muy concreto, el cenobita, que vivía en comunidad, bajo una regla y un abad. Un espacio, el del cenobio, que en la alta Edad Media también fue conocido como Ascysterium, término utilizado a mediados del s. IX por el cordobés San Eulogio a la hora de referirse a todos los cenobios ubicados en las cercanías de Córdoba, pero también a alguno de los que visitó en el viaje que le condujo hasta los Pirineos ${ }^{3}$. Y el monasterium era, también según san Isidoro, la habitación de un solo monje, ya que en griego "monos" significa "solo" y "sterion" "residencia". Es decir, el monasterio era la habitación de un solitario, solitarii habitatio: "construcciones para solitarios" o "construcciones monásticas" que, por tanto, nada tienen que ver con el contenido que actualmente otorgamos - de manera convencional, al menos en España - al término monasterium, que no es sino el que originariamente tuvo la expresión coenobium ${ }^{4}$. Un uso mucho más tardío y mucho más esporádico, casi anecdótico, tendrá la expresión

${ }^{1}$ A.M. MARTÍNEZ TEJERA, La realidad material de los monasterios y cenobios rupestres hispanos (siglos V-X), in Monjes y monasterios hispanos en la Alta Edad Media, Aguilar de Campoo, 2006, p. 59-97; ID., El hábitat 'cenobítico' en Hispania: organización y dependencias de un espacio elitista en la Antigüedad Tardía y Alta Edad Media (siglos V-X), in Monasteria et Territoria. Elites, edilicia y territorio en el mediterráneo medieval (siglos V-XI), Archaeological Studies on Late Antiquity and Early Medieval Europe (400-100 A. D.) eds. S. Gelichi, J. López Quiroga, P. Perin, Conference Proccedings II; J. LOPEZ QUIROGA - A.M. MARTÍNEZ TEJERA - J. MORÍN DE PABLOS (eds.), Oxford, 2007, p. 19-76. Conclusión (lo que puede significar la diferenciación monasterium/ coenobium desde el punto de vista arquitectónico y arqueológico) que ha sido acogida y asumida posteriormente por otros autores con total naturalidad, por ejemplo: F.J. MORENO MARTÍN, La configuración arquitectónica del monasterio hispano entre la tardoantigüedad y el alto medievo. Balance historiográfico y nuevas perspectivas, in Cien años de investigación sobre arquitectura medieval española, Madrid, 2009, p. 199-217; ID., Los escenarios arquitectónicos del eremitismo hispano. Límites para su estudio, in El monacato espontáneo. Eremitas y eremitorios en el mundo medieval, Aguilar de Campoo, 2011, p. 85-119; I.G. BANGO TORVISO, La imagen del monasterio hispano. Algunas reflexiones sobre su estructura y significado, in El Monacato en los reinos de León y Castilla (siglos VII-XIII), X Congreso de Estudios Medievales, León, 2007, p. 175-212; ID., Imagen del monasterio medieval. La realidad iconográfica funcional y la seductora invención iconológica de la evocación, in Los monasterios medievales en sus emplazamientos: lugares de memoria de lo sagrado, XXIX Semana de Historia del Monacato, Palencia, 2016, p. 283-307, especialmente p. 289-294.

${ }^{2}$ Etimologías, Texto latino, versión española, notas e índices por J. Oroz Reta y M.A. Marcos Casquero, Biblioteca de Autores Cristianos, nํㅗ $433-434$, I (libros I-X), II (libros XI-XX), Madrid (2ª edic. Madrid 1993-1994), I, p. 682; II, p. 234-235 y 238-239.

3 "En los diplomas astur-leoneses del s. X volveremos a encontrar esta expresión con ligeras variantes gráficas pero con idéntico significado, curiosamente en cinco documentos datados entre los años 945-978 procedentes a Sahagún. En definitiva un helenismo de uso escaso y restringido que también se utilizó para hacer alusión al conjunto de edificios al servicio de una comunidad estable": A.M. MARTÍNEZ TEJERA, Arquitectura monástica en tiempos de San Genadio (¿865?-935/937): San Miguel de Escalada y Santiago de Peñalba (prov. de León), Tesis Doctoral, Universidad Autónoma de Madrid (Madrid 2004), III, inédito, p. 77 .

${ }^{4}$ Las fuentes de la época, y no la arqueología, ni el positivismo (como se ha indicado; F.J. MORENO MARTíN, 2011, op. cit. (n. 1), p. 112, nota no 2), hablan de la existencia de celdas individuales y lauras eremíticas (monasterios) tanto en el ámbito urbano como en el rural en Hispania desde finales del s. IV, momento en el que tenemos constancia de la presencia de ancillae, de vírgenes y ascetas: A.M. MARTÍNEZ TEJERA, Reflexiones en torno a la edilicia cristiana en la tardo-antigüedad hispana (ss. IV-VII) (I), in Galia e Hispania en el contexto de la presencia 'germánica' (ss. V-VII), Archaeological Studies on Late Antiquity and Early Medieval Europe (400-100 A. D.), ed. S. Gelichi, J. López Quiroga, P. Perin. Conference Proccedings II; J. LOPEZ QUIROGA 
monasteriolum, un diminutivo de monasterium que aparece en un documento de la primera mitad del año $943^{5}$.

¿Podemos mantener esta distinción para la Alta Edad Media? Como ya señaló Puertas Tricas, en los ss. IX-X ya predominaría el uso del término monasterium a la hora de referirse a un espacio de vida comunitario ${ }^{6}$. Los testimonios escritos son abundantísimos y su presencia en la documentación altomedieval, una constante, incluso a la hora de hablar, por ejemplo, de algo tan ibérico como fueron las comunidades dúplices, al menos para la novena centuria y en territorios dominados por el islam. Además, los hábitats monásticos y/o cenobíticos altomedievales hispanos recibieron otras muchas denominaciones, algunas carentes de cualquier connotación religiosa. Este es el caso de atrium, cella, cellula o domus, esta última (domum sororis) utilizada por San Eulogio, a mediados del s. IX, al hablar del cenobio de Tábanos, y que aparece a finales de dicha centuria (c. 893) en San Salvador de Valdediós (Asturias): D[OMI] NI ET SALVATORIS N[O]S[TR]I CUIUS EST DOMUS ISTA7.

$Y$ si para conocer el monasterio tardoantiguo hispano podíamos recurrir a varias regulae de autoría conocida ${ }^{8}$, no sucederá lo mismo para el monacato altomedieval, ya que partir del siglo VIII apenas encontramos 'nuevas' reglas monásticas (o al menos todavía hoy no se conocen con precisión), a no ser que consideremos como tal - a pesar de sus continuas exhortaciones a observar debidamente las "Reglas de los Padres" - la anónima y conflictiva Sanctorum Pauli et Stephani abbatum Regula ad Monachos recogida por Benito de Aniano, llamada "Regla de los santos Pablo y Esteban”, probablemente redactada durante los primeros balbuceos de la monarquía asturiana9; una institución, la monarquía asturiana, que desde la segunda mitad del s. IX, sobre todo a lo largo del reinado del Alfonso III (a. 866-910), irá introduciendo progresivamente la preeminencia de la regla benedictina en el noroeste hispano ${ }^{10}$.

En Iberia los 'monasterios ortodoxos' fueron promovidos y patrocinados en la Alta Edad Media por la monarquía, la nobleza y el episcopado, en definitiva, por las élites, ya se encuentren estos en el norte peninsular o en el sur, en territorios dominados por el islam ${ }^{11}$. Lo que variara será el papel desempeñado por unos y otros en los distintos territorios (por ejemplo, en el sur no existen, por razones obvias, las fundaciones monásticas avaladas por la realeza cristiana, y el papel del obispo fue 'minimizado') ${ }^{12}$. Cabe destacar en este sentido, ya en la décima centuria hispana, la acción fundacional llevada a cabo en territorios cristianos por monarcas leoneses como García I (San Pedro de Eslonza, 910; San Miguel de Escalada, 913)13 (fig. 1), por nobles como Flammola y Gonzalo Téllez, fundadores del monasterio burgalés de San Pedro de Arlanza en el 912, y por obispos como el de Astorga, Iennadius, san Genadio, que - como ya dijo de él, en el 937, su sucesor en la silla episcopal de Astorga, el obispo Salomón - no solo construyó monasterios sino que también edificó "cenobios y eremitorios”. Un personaje, este Genadio, que primero fue monje cenobita en el monasterio Ageo, posteriormente abad de San Pedro de Montes, después obispo de Astorga y, finalmente, anacoreta en las cercanías de Peñalba de Santiago, otra de sus fundaciones 'monásticas'14 (fig. 2). A su acción se debe el renacimiento de la conocida como 'Tebaida berciana', un territorio monástico surgido en la primera mitad del s. VII en torno a la figura de san Fructuoso y su primera fundación, el coenobium complutense, construido en lo que eran sus posesiones familiares en El Bierzo. De su estructura y organización nada se sabe, pero si su localización ${ }^{15}$.

\footnotetext{
- A.M. MARTÍNEZ TEJERA - J. MORÍN DE PABLOS (eds.), Oxford, 2006, p. 109-187; ID., La arquitectura cristiana de los siglos V-VI en Hispania: entre la 'oficialización'y la 'expansión', in El tiempo de los ‘Bárbaros. Perivencia y transformación en Galia e Hispania, Alcalá de Henares, Zona Arqueológica no 11 , Madrid, 2010, p. 223-270.

${ }^{5}$ A.M. MARTÍNEZ TEJERA, op. cit. (n. 3), T. III, p. 81: in monasteriolo ubi uestra est decania.

${ }^{6}$ R. PUERTAS TRICAS, Iglesias hispánicas (siglos V al VIII). Testimonios literarios, in Temas de Arte, 4, Madrid, 1975, p. 104.

${ }^{7}$ A.M. MARTÍNEZ TEJERA, op. cit. (n. 3), T. III, p. 75.

${ }^{8}$ Nos referimos de manera muy especial, aunque no únicamente, a los textos redactados por Leandro e Isidoro, obispos de Sevilla, y por Fructuoso de Braga, todos ellos en el s. VII, además de las cronológicamente conflictivas Regula Magistri y Regula Communis: A.M. MARTÍNEZ TEJERA, Los monasterios hispanos (siglos V-VII). Una aproximación a su arquitectura a través de las fuentes literarias, in Los Visigodos y su mundo, I Jornadas Internacionales, Madrid 1990, Arqueología, Paleontología y Etnografía, 4, Madrid, 1997, p. 117-125. Poco después, mi entonces director de tesis, publicó una visión muy similar: I.G. BANGO TORVISO, El monasterio hispano. Los textos como aproximación a su topografía y a la función de sus dependencias, in Los monasterios aragoneses, Lacarra M.C. (coord.), Zaragoza, 1999, p. 7-24.

${ }_{9}^{9}$ Recogida por Benito de Aniano, "para Dom Berliere, Pabloy Esteban no serían sus autores sino los santos titulares a los que estaría dedicado el monasterio, que sitúa geográfica y cronológicamente en la provincia de Lugo y fundado o restaurado por los monjes de Samos hacia el 789 en tiempos del monarca astur Vermudo I), frente a Salvatore Pricoco, que opina que la procedencia de esta regla sería Italia, o Evangelista Vilanova, que la considera una recopilación de la obra de San Basilio realizada por Rufino": A.M. MARTÍNEZ TEJERA, op. cit. (n. 3), T. I, p. 184.

${ }^{10}$ Tan progresiva, que a finales del s. XI, principios del XII, todavía la regla benedictina no era preeminente en el reino de León: A.M. MARTÍNEZ TEJERA, Cenobios leoneses altomedievales ante la europeización: San Pedro y San Pablo de Montes, Santiago y San Martín de Peñalba y San Miguel de Escalada, in Hispania Sacra, LIV, 109, Madrid, 2002, p. 87-108. Ni siquiera en la 'Marca Hispánica', en donde también encontramos “monasterios regidos por un codex que recogía citas eruditas tan orientalistas como las basilianas, como en los monasterios de Serrateix (fundado en el 940) y Amer. Lo que no quiere decir que cuando, avanzado el s. X, se acredite la advocación y vigencia de una norma única, ésta no sea otra que una adaptación o actualización de la de San Benito, como ocurre en el cenobio aragoneses y catalanes (Siresa, 833; Bañones, 882). Para la península ibérica no tenemos constancia de que ocurriese lo mismo que allende los Pirineos tras los sínodos de Aquisgrán ( 816 y 817), que los cenobios y abades que no fueran capaces o no quisieran adoptar la nueva disciplina monástica - es decir, la regla benedictina reformada - quedarían equiparados, por voluntad imperial, a los canónigos": ID., op. cit. (n. 3), T. I, p. 189. "ID., op. cit. (n. 1).

${ }^{12}$ ID., La arquitectura de la comunidad dimmiyyun (siglos IX-X): 'arquitectura del pacto' y 'arquitectura de resistencia', in Codex Aquilarensis (Cuadernos de Investigación del Monasterio de Santa María la Real, 19) Palencia, 2003, p. 48-72.

${ }_{13}^{13}$ ID., El templo del monasterium de San Miguel de Escalada: "arquitectura de fusión" en el antiguo reino de León (siglos X-XI), Madrid, 2005.

${ }^{14}$ ID., La ecclesia de Santiago de Peñalba (El Bierzo, León). Arquitectura de Fusión del siglo X en el antiguo reino de León, Madrid, 2010, p. 27-49.

${ }^{15}$ J. LÓPEZ QUIROGA - A.M. MARTÍNEZ TEJERA, Un monasterium fructuosiano por descubrir: el de Compludo, en El Bierzo (prov. de León), in Argutorio, in Revista de la "Asociación Cultural Monte Irago, VI, 12, Astorga, 2007, p. 43-47.
} 


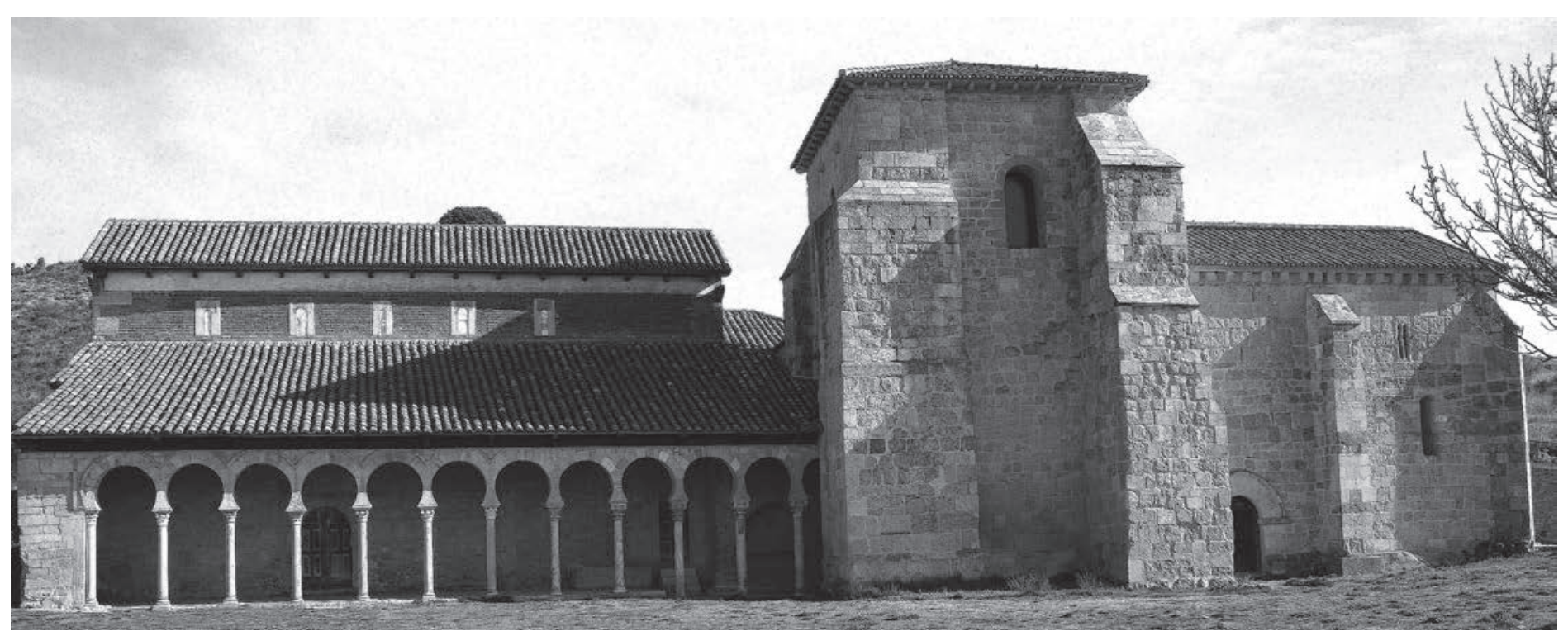

Fig. 1 Conjunto arquitectónico de San Miguel de Escalada (León): a la izquierda, fachada sur de la iglesia altomedieval (s. X) dedicada a San Miguel, con su pórtico columnado, este último materializado a mediados del s. XI con elementos reaprovechados, y a la derecha la iglesia románica (ss. XII), dedicada a San Fructuoso (más tarde conocida como "Capilla de San Gonzalo" o "Panteón de los Abades"). Y entre ambas una torre erigida entre finales del s. XI y principios del s. XII (@Artemio M. Martinez Tejera).

El espacio monástico se constituye - ya desde la Antigüedad Tardía - como otra forma de poblamiento surgida más allá de las villae et vicii, tal y como acaeció en Oriente también por los mismos momentos (ss. VI-VII), donde sabemos que unos y otros mantuvieron una relación geográfica y económica muy estrecha ${ }^{16}$. ¿Alguien puede dudar de que en torno a las 'aldeas espirituales' - elementos de cristianización y evangelización en la Antigüedad Tardía - surgieron, en la Alta Edad Media hispana, muchas 'aldeas y villas laicas'? Por lo que sabemos hasta ahora, el monasterio hispano de los ss. IX-X podía estar regulado en torno a una única disposición, normativa o regla, o bien hacerlo por disposiciones extraídas de distintas regulae. En aquellos siglos serán el Codex Regularum y el Geronticon o "Vida de los Padres" ${ }^{17}$ los compendios que inspiren la disciplina espiritual de nuestro monjes altomedievales, sin duda un rasgo más del eclecticismo que rigió la espiritualidad monástica de aquellos siglos, tanto en territorios libres como dominados.

No obstante, y a pesar de la precariedad documental, varios son los códices regulares de este periodo que todavía se conservan. De cronología conflictiva (ss. VIII-X) es el custodiado en El Escorial, el llamado "Códice de Leodegunda", estudiado en la primera mitad del s. XX, y que incluye las legislaciones de Pacomio, Jerónimo, Agustín, Benito, Leandro, Isidoro y Fructuoso ${ }^{18}$. A esta Leodegunda se la supone monja del monasterio de Bobatella: ¿acaso del monasterio de San Félix de Bobatiella, en Saelices de Mayorga (prov. de Valladolid), una posibilidad más en consonancia con otras opiniones que lo situaron en Tierra de Campos?'19 Y a la décima centuria pertenecen los códices burgaleses de

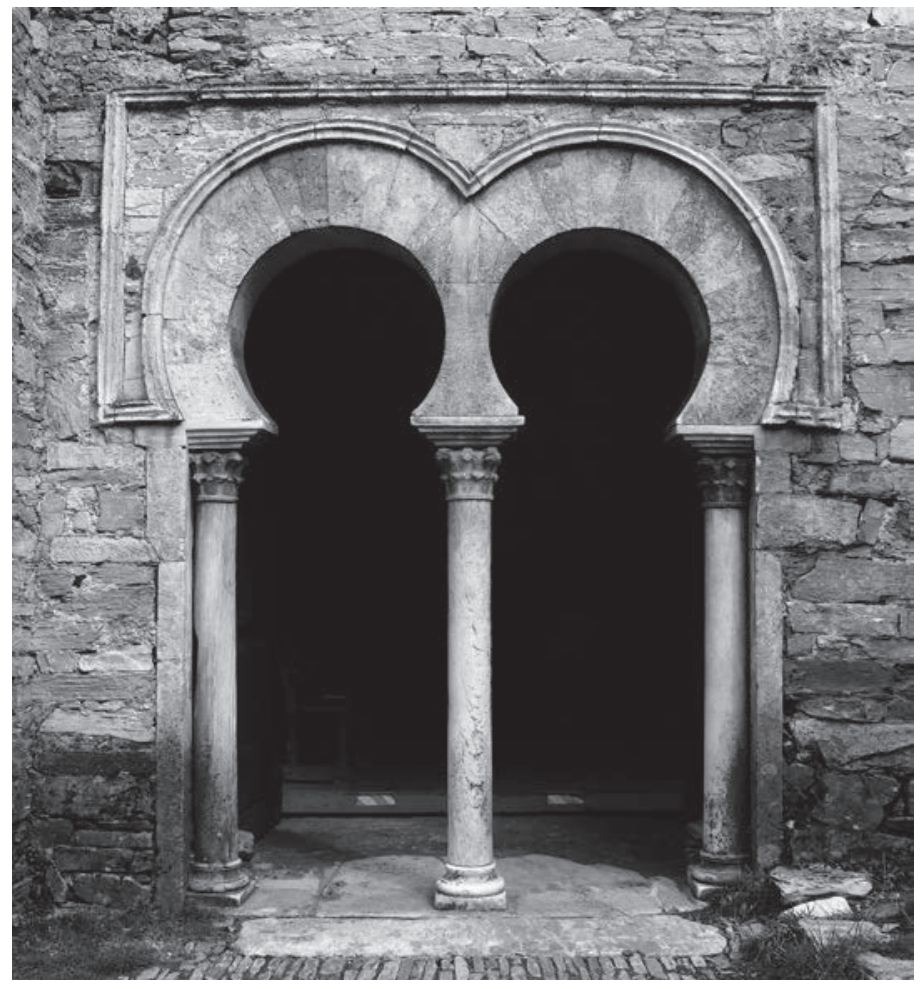

Fig. 2 Acceso meridional a la iglesia monástica de Peñalba de Santiago (León), consagrada el a. 937 por Salomón, obispo de Asturica Augusta (Astorga), aunque fundada por su predecesor, el obispo Genadio de Astorga. Elementos ornamentales como el alfiz cerrado o la bóveda gallonada aparecen por vez primera en la arquitectura cristiana hispana (@Artemio M. MartinezTejera).

\footnotetext{
${ }^{16}$ A.M. MARTINEZ TEJERA - J. LÓPEZ QUIROGA, La soledad en el yermo como génesis de un 'nuevo' sistema de poblamiento más allá de ciudades y villas: los Monasteria et Coenobia hispanos de la Antigüedad Tardía (ss. V-VII), in Gundemarus y la iglesia visigoda a comienzos del siglo VII, X Seminario Internacional de Historia (2-3 de noviembre de 2010, Museo Arqueológico de Elda-Universidad de Alicante), en prensa.

${ }^{17}$ Que encontramos en el códice misceláneo de la Seo de Urgel, un códice de marcado contenido monástico realizado en el a. 928: M.C. DÍAZ Y DÍAZ, Manuscritos visigóticos del sur de la península. Ensayo de distribución (Servicios de Publicaciones de la Universidad de Sevilla, Serie Historia y Geografía, 11), Sevilla, 1995, p. 127-129.

${ }^{18}$ ID., El códice monástico de Leodegunda (El Escorial a.I.13), in Ciudad de Dios, 181, El Escorial, 1958, p. 567-587.

${ }^{19}$ A.M. MARTÍNEZ TEJERA, Iglesia de San Pedro. Saelices de Mayorga, in Enciclopedia del Románico en Castilla y León. Valladolid, dir. M.Á. García Guinea, J.M. Pérez González, Aguilar de Campoo, 2002, p. 321-326.
} 
Arlanza y Cardeña, el primero - ahora desaparecido - con los textos de Pacomio, Basilio, Macario, Agustín, Benito, Isidoro y Fructuoso y el segundo con las obras de Pacomio, Basilio, Orseisio, Fausto y Fructuoso, además de la conocida como Regula Consensoria Monachorum ${ }^{20}$. Es decir, la tradición continúa. Y si las normas apenas varían habrá que pensar que tampoco lo hizo la estructura de nuestros cenobios y su configuración.

Y destacar por último uno de los documentos que aparece al final del comentario que de la regla de San Benito realizó el monje Smeragdo de Saint-Mihiel, el conocido como "Penitencial”, que se estructura en dos partes: la primera, Ex regula cuiusdam, reúne fragmentos, como no, de las Reglas de los Santos Padres y una segunda, Qui debeant fratres uel sorores in monasterio observare (de título prácticamente idéntico a alguno de los caps. X-XII y XIX-XX de la Regula Communis, elaborada en la $2^{-\underline{a}}$ mitad del siglo VII, c. 656) ${ }^{21}$ que pudo haber ido destinada a regular la vida de monasterios dúplices, los habitados simultáneamente por dos comunidades de sexo diferente, separadas una de otra físicamente y con un único superior, y mixtos, en donde monjas y religiosas viven en común que pudo haber ido destinado a regular la vida de monasterios dúplices ${ }^{22}$.

La pervivencia del sistema pactual monástico en el reino astur-leonés hasta la segunda mitad del s. XI es, junto con la tardía benedictinización del monacato, uno de los temas más complejos y controvertidos ${ }^{23}$. En aquellos momentos la vida monástica hispana todavía estaba sujeta a interpretaciones muy personalistas pero, eso sí, ahora siempre (o casi siempre) dentro de la ortodoxia. Y uno de los casos más sugerentes es el resurgir espiritual de territorios como la 'Ribera Sacra', surgida a partir de la fundación del 'monasterio Peonense' en la confluencia de los ríos Miño y Sil, una fundación fructuosiana o la 'Tebaida berciana' en la décima centuria $^{24}$. Un resurgir... ¿de la mano del benedictinismo? Como decimos, los 'personalismos' siguen predominando y así nos encontramos con dos figuras coetáneas como son san Rosendo, fundador del monasterio orensano de 'Cella
Nova' y san Genadio de Astorga, fundador del monasterio leonés de Penna Alba (Peñalba de Santiago, prov. de León), el primero de espíritu claramente benedictino y cenobítico y el segundo de clara inspiración fructuosiana y solitaria ${ }^{25}$.

En los ss. IX-X, y para el reino de León, apenas existe constancia documental de esta 'preeminencia benedictina' si exceptuamos - y no sin ciertas dudas - los monasterios leoneses de San Pedro de Montes, Abellar y San Isidro de Dueñas, pero sí que la hay de la jurisdicción episcopal sobre los cenobios. La novedad más significativa con respecto a siglos precedentes será la imparable popularidad de la Regula monachorum de san Benito de Nursia, hasta el punto de que era de sobras conocida en la península en la primera mitad de la décima centuria, como ya demostró Antonio Linage ${ }^{26}$. Pero como muy bien señaló el padre Colombás en 1991, refiriéndose a la tradición benedictina altomedieval (ss. VIII$\mathrm{XI}$ ), "el ordo monasticus no se convierte en benedictino de la noche a la mañana. Persiste la regula mixta. Los abades no se resignan a someterse a una sola regla, y las comunidades a renunciar a sus tradiciones. La regla benedictina se propaga pero no domina, pese a los esfuerzos por imponerla" 27 . En lo que existe un mayor acuerdo es en aceptar la vigencia de la Regula Communis o "Regla de los Abades" en la alta Edad Media, pues aparece reflejada en el documento (a. 861) en el que Ordoño I confirma al abad Ofilón los bienes adquiridos por el monasterio de Samos desde tiempos del abad Argenio, al que presenta como el máximo representante de una confederación monástica instalada en la más pura tradición del siglo $\mathrm{VII}^{28}$.

Y tampoco conocemos fuentes canónicas que hablen del tema. A partir del s. VIII - y al menos basándonos en los textos reconocidos como tales hasta el día de hoy - las reuniones conciliares fueron cada vez más escasas y esporádicas. Y cuando se produjeron se limitan casi siempre a un ámbito provincial, ya se celebren en territorios bajo dominio musulmán (concilios de Sevilla, a. 784 y Córdoba, a. 839 y a. $851 / 852)^{29}$ o en territorios libres (los conflictivos concilios celebrados en Oviedo a lo largo de los ss. IX - a. 811 - y X, ya

\footnotetext{
${ }^{20}$ CH.J. BISHKO, The Date and Nature of the spanish Consensoria Monachorum, in American Journal of Philology, 69, 1948, p. 377-395. Para algunos investigadores, se trata de una regla relacionada con el Priscilianismo: D. DE BRUYNE, La "Regula Consensoria". Una règle des moines priscillianistes, in Revue Bénédicitine, 25, 1908, p. 83-88.

${ }^{21}$ Su texto en San Leandro, San Fructuoso, San Isidoro. Reglas monásticas de la España visigoda. Los tres libros de las "Sentencias”, ed. crítica bilingüe por J. Campos Ruíz e I. Roca Melia, II (Biblioteca de Autores Cristianos 321 “Santos Padres Españoles”), Madrid, 1971, p. 172-211.

${ }^{22}$ M.C. DÍAZY DÍAZ, Para un estudio de los penitenciales españoles, in Melanges aofferts a Edmond-Renè Labande. Ėtudes de Civilisation Médiévale, IXe-XIII ${ }^{e}$ siècles, Paris, 1974, p. 217-222; ID., Passiónaires, légendiers et compilations hagiographiques dans le Haut Moyen Âge espagnol, in Colloque sur Hagiographie, Cultures, Sociétés IV $V^{e}-1 X^{e}$ siècles, Paris, 1981, p. 495 y ss.

${ }^{23}$ No obstante, recordaremos "entre los pactos más antiguos conocidos destacar el establecido entre la abadesa Nonna Bella y una quincena de monjas en el monasterio de San Miguel de Pedroso, cerca de Belorado (prov. de Burgos), en el 759; el de Lucis, otorgado por el rey Silo con Petrus y sus monjes (775); el de Montano y sus monjes con Fromistano en San Vicente de Oviedo (781) y el de Salceda (873). [...] Documentos que han servido para hablar de la pervivencia de un monaquismo autóctono hispano, con características propias, al menos hasta el 950, en zonas como El Bierzo ("el nuevo Bierzo monástico", como lo llamará Lambert) y Galicia": A.M. MARTÍNEZ TEJERA, op. cit. (n. 3), T. I, p. 186.

${ }^{24}$ ID., Peñalba de Santiago y las Cuevas del Silencio, in Historia 16, 265, Madrid, 1998, p. 94-99. ID., La 'Tebaida Berciana' en tiempos de San Fructuoso (siglo VII), in Argutorio (Revista de la Asociación Cultural Monte Irago"), VII, 12, Astorga, 2004, p. 43-45.

${ }^{25}$ ID., La iglesia de Peñalba de Santiago (El Bierzo, León): el santuario de un héroe espiritual de los siglos IX y X, in Argutorio, XIV, 26, Astorga, 2010, p. 42-48; M. GUARDIA PONS, El oratorio de San Miguel de Celanova: arquitectura y liturgia, in Rudesindus. La cultura europea del siglo X, Catálogo de la Exposición, Xunta de Galicia, Santiago de Compostela, 2007, p. 130-143.

${ }^{26}$ A. LINAGE CONDE, Los orígenes del monacato benedictino en la Península Ibérica, Colección "Fuentes y Estudios de Historia Leonesa”, 9-11, León, 1973. ${ }^{27}$ G.M. COLOMBÁS, La tradición benedictina. Ensayo histórico, III, Zamora, 1991, p. 11.

${ }^{28}$ J. ORLANDIS ROVIRA, Legados de la España visigótica, in Alfonso VIII y su época, II Curso de Cultura Medieval, Aguilar de Campoo, 1992, p. 153-16o, especialmente p. 157 .

29 "El primero, localizado en un códice legionense, vino motivado por la herejía acéfala, seguidora de Vigilancio y su negativa a la adoración de las reliquias de los santos y el segundo, convocado por Abd al-Rahman II y presidido por el bético obispo Recafredo, para condenar ambiguamente la reacción martirial de una parte de la población cordobesa. El texto del concilio del 839 se encuentra en el denominado "Códice samuélico de León" (Biblioteca Capitular, códice 22), con origen paleográfico en Córdoba hacia el 830”: A.M. MARTíNEZ TEJERA, op. cit. (n. 3), T. I, p. 49, n. 211.
} 
en el reinado de Alfonso III, o el celebrado en León el año 950 presidido por Ramiro II) ${ }^{30}$.

El monacato hispano de los ss. VIII al XI - al menos en el caso del territorio del reino de León (a. 910-1037), uno de los protagonistas principales de la reorganización políticoadministrativa de los territoria -, conservará muchos de los rasgos propios del movimiento en sus orígenes (marginalidad y ruptura), sobre todo en los territorios bajo control islámico y por cuestiones obvias. En estos últimos 'los monjes dímmíes' son "los monjes del pacto" o "monjes de la clientela", los monjes protegidos. ¿Sabemos cómo fueron los monasterios de los mal llamados "mozárabes"? No, desde el punto de vista material apenas nada, pues en muchos casos su simple localización todavía sigue siendo muy conflictiva. Pero de que existieron, no cabe duda, y la Historia, a partir de los textos, así lo manifiesta en infinidad de ocasiones ${ }^{31}$.

Para la Alta Edad Media contamos con abundante documentación en la que el monasterio es uno de los grandes protagonistas nominales, pero si de lo que se trata es de averiguar a partir de los textos la estructura física y organización de las distintas estancias o dependencias que lo conformaban, los textos guardan silencio. Y todavía resulta más difícil saber si este se desarrolló 'en extensión', distribuido en decaniae (del término latino decanus), es decir de grupos de 10 monjes bajo la responsabilidad o supervisión de un decanus, como permitía la Regula Communis en su cap. XII delimitando las funciones del decano con respecto a los monjes que estaban a su cargo, estableciendo que fueran los prepósitos los encargados de indicar el día y lugar en el que los decanos, junto con sus monjes, debían reunirse en un lugar del monasterio ${ }^{32}$. En la documentación altomedieval (a. 860-975) el término decania se utilizó tanto como sinónimo de hábitat comunitario como en el de posesión incluida dentro de un monasterio, es decir, el territorio en el que se ubica33. Todo parece apuntar a que en la alta Edad Media estas decanías ya se habían convertido en pequeñas células espirituales autónomas en su funcionamiento pero dependientes o sujetas a un núcleo cenobítico de mayor envergadura material y espiritual ${ }^{34}$. El hecho de que sea el prepósito del cenobio el encargado de indicar al decano el día y lugar del monasterio en el que debían reunirse, significa que estas decaniae se encontraban también bajo la obediencia de un abad y sometidas a una legislación monástica, aunque no compartieran un mismo espacio habitacional. Lo que ya resulta más complejo es definir su materialización y localización, si bien los textos parecen indicar que las decanías serían estructuras independientes, separadas unas de otras.

¿Y qué supuso la fecha del 711 para los monasterios hispanos? La división político-religiosa en territorios - a grosso modo - dominados por el islam y en territorios cristianos libres supuso la fractura de la unidad de la Iglesia, que desde entonces y hasta el año 1085, con la conquista de Toledo, contó con dos centros de poder espiritual (Toledo y Oviedo) que mantuvieron intensas disputas teológicas desde el s. VIII (recordemos las disputas de Beato de Liébana y el obispo Elipando de Toledo sobre la cuestión adopcionista). Una bicéfala iglesia hispana que no consideró la cuestión monástica y a ella solo se referirá, de manera testimonial, a finales del s. IX (a. 88o-89o aprox.), el anónimo redactor de la Crónica Albeldense para decirnos que el monje Antonio (san Antonio el Grande, a. 251-356 aprox.) fue el primer fundador de "monasterios", pero utilizando el término en el sentido de 'cenobio', tal y como se correspondía con las fundaciones monásticas de entonces ${ }^{35}$. Pero resulta que el primer fundador de 'cenobios' fue san Pacomio (a. 286-346 aprox.), "el padre del cenobitismo", fundador de la koinonia o comunidad estable; Antonio fue el más ilustre de entre los primeros anacoreta, y por tanto, un fundador de 'monasterios', no de 'cenobios'. Esto indica que, en efecto, a finales del s. IX el término monasterium ya se utilizaba con el sentido de cenobium.

\section{LAS 'ALDEAS ESPIRITUALES’ HISPANAS EN LA ALTA EDAD MEDIA}

Por lo que cuentan los textos, en la alta Edad Media peninsular coexistieron tres tipos de hábitats 'monásticos': el individual, propio del anacoreta, el eremítico, propio del (que a veces podía generar una lavra o laura, un espacio para solitarios con ciertos ámbitos destinados a actividades comunitarias), y, finalmente, el comunitario o cenobítico, que es del que nos vamos a ocupar aquí. Queda fuera de nuestro análisis el tema de la arquitectura monástica rupestre y semirupestre, tan apasionante como complejo ${ }^{36}$.

\subsection{La 'aldea espiritual' en los territorios cristianos: organi- zación y dependencias}

Desde mediados del siglo IX el avance de la frontera cristiana, especialmente con Alfonso III de Asturias, requirió una nueva respuesta política y ésta se baso, fundamentalmente,

${ }^{30}$ Para los concilios asturianos: F.J. FERNÁNDEZ CONDE, La iglesia de Asturias en la Alta Edad Media, Oviedo, 1972, p. 38-40. Para los de León: M. CARRIEDO TEJEDO, El concilio de León del año 950, presidido por Ramiro II, in Tierras de León, XXXIV, 93-94, León, 2004, p. 3-30.

${ }^{31}$ A.M. MARTÍNEZ TEJERA, op. cit. (n. 12).

${ }^{32}$ Decani qui super decanias sunt constituti tantam sollicitudinem gerant super quos delegatos habent fratres, ut nullas proprias faciant uoluntates [...] Omnes decani a suis praepositus admoneantur ut cuncti fratres a minimo usque ad maximum diebus dominicis in monasterio uno loco congregentur [...] et non plus quam septem dies interponere [...]: San Leandro, San Fructuoso, op. cit. (n. 21), p. 192.

33 Ibidem, p. 120.

34 "Se trata de una expresión con la que en determinadas ocasiones se hacía alusión a pequeñas células espirituales autónomas en su funcionamiento - generalmente compuesta por no más de 10 miembros, de ahí su nombre - pero dependientes o sujetas a un núcleo cenobítico de mayor envergadura material y espiritual. No obstante siempre que aparece en documentos que rondan el año 10oo, parece identificar un nuevo encuadramiento social dependiente del señorío, en definitiva un término que sugiere un acelerado proceso de adscripción física y social de los hombres": A.M. MARTÍNEZ TEJERA, op. cit. (n. 3), T. III, p. 77.

${ }^{35}$ Crónicas Asturianas. Crónica de Alfonso III (Rotense y "A Sebastian"). Crónica Albeldense (y "Profética"), Introducción y ed. crítica de J. Gil Fernández, Traducción y notas de J.L. Moralejo, Estudio preliminar de J.I. Ruiz de la Peña, Oviedo, 1985, p. 233.

${ }^{36} \mathrm{Al}$ que hemos dedicado varios estudios: A.M. MARTÍNEZ TEJERA, op. cit. (n. 1), 2006; ID., PER SPELUNCAS ET RUPES... Los 'espacios monásticos' en El Bierzo, de San Fructuoso de Braga a San Genadio de Astorga (siglos VII-X), in In concavis petrarum habitaverunt. El fenómeno rupestre en el Mediterráneo Medieval: de la investigación a la puesta en valor, J. López Quiroga - A.M. Martínez Tejera (eds.), Conference Proceedings 4, Oxford, 2014, p. 117-151. 
en la reestructuración y reorganización de los territorios; un proceso en el que la intervención de la Iglesia, en general, y del movimiento monástico en particular, resultó fundamental, y de ella se valió la monarquía astur-leonesa, que favoreció las fundaciones cenobíticas y permitió la existencia de asentamientos de todo tipo de monjes, eremitas y anacoretas incluidos. Pero de asentamientos controlados, y para ello los reyes se apoyaron en la figura del episcopus, al que en muchos ocasiones "obligaron" a ocupar tal dignidad. Uno de estos obispos fue, como ya hemos dicho, Genadio de Astorga. Hay que subrayar la trascendencia de su figura, la de un auténtico "anacoreta", un "eremita honesto" que disfrutó de la vida en soledad en el último tramo de su vida, después de haber formado parte de las comunidades cenobíticas de Ageo y de San Pedro de Montes. Su actuación al frente del obispado asturicense ejemplifica una actitud más tolerante, por parte de la alta jerarquía eclesiástica, hacia la práctica solitaria, una forma de vida tradicional aceptada y prestigiada en la Gallaecia que hacía siglos había entrado a formar parte de las estructuras económicas dominantes y del dominio del episcopado, toda vez que se había convertido, en definitiva, en un factor de cohesión social y religiosa ${ }^{37}$.

En los territorios cristianos, el influjo o concepción ascética predominante entre los monjes y obispos de tal o cual región todavía condicionó la manera en la que se concibió el 'espacio monástico' y su impacto sobre el territorio. Hubo distintas espiritualidades y, por tanto, maneras muy diferentes de concebir el espacio. No obstante, su distribución y organización dependerá de factores tan dispares como la normativa seguida, el número de monjes que la componen, su actividad económica predominante, su ubicación geotopográfica (urbano, rural, en el interior, en la costa), el tipo de colectividad que lo habitaba ( o dúplices, estos últimos con su origen en el gobierno espiritual y material de los monasterios femeninos por los de varones), etc.

Si fuera por lo que sabemos hasta ahora, diríamos que la fundación de estos centros no habría estado limitada por disposiciones canónicas, como sabemos que ocurrió en la Antigüedad Tardía, desde al menos mediados del s. VI. Un periodo en el que la cantidad máxima que un obispo podía destinar a la construcción de una iglesia monasterial (según el canon V del IX Concilio de Toledo, a. 655), no podía superar en la 1/50 parte de los bienes de su sede ${ }^{38}$. Aquí nos encontramos con un gran condicionante constructivo que también encontraremos en la alta Edad Media: el económico, y especialmente en los territorios dominados por el fisco musulmán. Sin embargo, sabemos por la Regula Communis que para la fundación de un nuevo monasterio era necesaria la consulta a la conferencia general 39 .

Condicionantes por un lado y acondicionamientos por otro, marcarán los primeros momentos de la vida de cualquier cenobio hispano, pues a la par que la construcción de los edificios cenobíticos, si no antes, se llevaba a cabo el acondicionamiento del terreno, garantizándose así la existencia de espacios cultivables que posibilitasen la alimentación de la comunidad. Baste recordar como en la restauración efectuada por el entonces monje Genadio en San Pedro de Montes (895), las llevadas a cabo en el monasterio leonés de los Santos Cosme y Damián de Abellar el año 927 o en el orensano de San Salvador de Celanova a mediados del s. X. De esta forma se dotaba al conjunto de una serie de espacios que, como complemento a las estancias o edificaciones propiamente monásticas, iban destinados a cubrir las necesidades más elementales de la comunidad, entre otros el jardín monástico, que ya estudiamos hace bastantes años ${ }^{40}$.

¿Cómo se organizaban nuestros cenobios? Antes de intentar responder a esta cuestión hay que advertir que muchos de los edificios que compondrán el organigrama cenobítico ideal que vamos a esbozar, y que como tales aparecerán en los textos, no son ni mucho menos exclusivos de este tipo de hábitat. De hecho no resulta muy difícil encontrar otro tipo de edificios religiosos incluso fuera de la península con, prácticamente, las mismas instalaciones: por poner un ejemplo, la domus episcopal de Lorenzo I en Milán (primera mitad del s. VI) contaba - según testimonios escritos - entre otras estancias con triclinium, oratorium, scriptorium, olearium, horreum, cellarium, coquina, hortus y balneum ${ }^{4}$. Pero, una cosa son los textos y otra los restos. Al día de hoy, las estancias señaladas por los textos todavía superan con creces a las exhumadas por la Arqueología. Como también superan -cuantitativamente hablando - los monasterios y cenobios recogidos por los textos (en mucho mayor número para la alta Edad Media) a los descubiertos por la Arqueología o a los parcialmente conservados, que en España apenas alcanza la veintena de conjuntos.

San Isidoro describió - en el cap. I de su Regula Monachorum - el espacio habitado por cenobitas como lo hiciera san Pacomio, pues fueron los cenobios pacomianos del s. III los primeros en rodearse por una cerca o muro con una clara función de defensa y protección contra el entorno, entonces pagano y hostil: Monasterii autem munitio tantum ianuam secus habebit et unum porticum per qua eatur ad hortum ${ }^{42}$. Así presentará también san Isidoro su modelo de 'aldea espiritual' del s. VII, como un recinto cerrado y dotado de un único acceso, que garantizaba su mayor fortificación y defensa (munitio), y de una puerta trasera o postigo a través del cual poder acceder a un huerto, este último incluido dentro del recinto claustral con el fin de que los monjes no tuvieran ocasión de vagar por el exterior. ¿Estuvieron los cenobios hispanos altomedievales acotados físicamente mediante algún tipo de fortificación permanente? Responder esta pregunta desde la Arqueología resulta, por el momento, casi imposible. Únicamente los hallazgos realizados en Santa María de Melque o en San Miguel de Escalada parecen corroborar, a priori, este punto ${ }^{43}$ (figs. 3-4). Sobre la existencia

\footnotetext{
${ }_{37}$ A.M. MARTÍNEZ TEJERA, op. cit. (n. 3), T. II, p. 258.

$3^{8}$ J. VIVES GATELL - T. MARÍN - G. MARTÍNEZ DÍEZ, Concilios visigóticos e hispanorromanos, Colección España Cristiana, Textos, I, Barcelona-Madrid, 1963, p. 300-301; R. PUERTAS TRICAS, op. cit. (n. 6), p. 127.

39 San Leandro, San Fructuoso, op. cit. (n. 21), cap. I, p. 173.

$4^{\circ}$ A.M. MARTÍNEZ TEJERA, El Jardín monástico Medieval (ss. IV-XI), in Codex Aquilarensis (Cuadernos de Investigación del Monasterio de Santa María la Real no 7), Palencia, 1992, p. 117-156.

${ }^{41}$ S. LUSUARDI SIENA, Commitenza laica ed ecclesiatica in Italia settentrionalle nel Regno Goto, in Committenti e Produzione artistico-letteraria nell 'alto medioevo occidentale, XXXIX Settimane di Studio del Centro Italiano di Studi sull'alto medieovo, Spoleto, 1992, p. $230-231$.

${ }^{42}$ San Leandro, San Fructuoso, op. cit. (n. 21), p. 91; A.M. MARTÍNEZ TEJERA, op. cit. (n. 40), p. 125; ID., op. cit. (n. 8), p. 120.

${ }^{43}$ Más factible, como veremos más adelante, en el caso del monasterio toledano (Melque) que en el leonés (Escalada).
} 


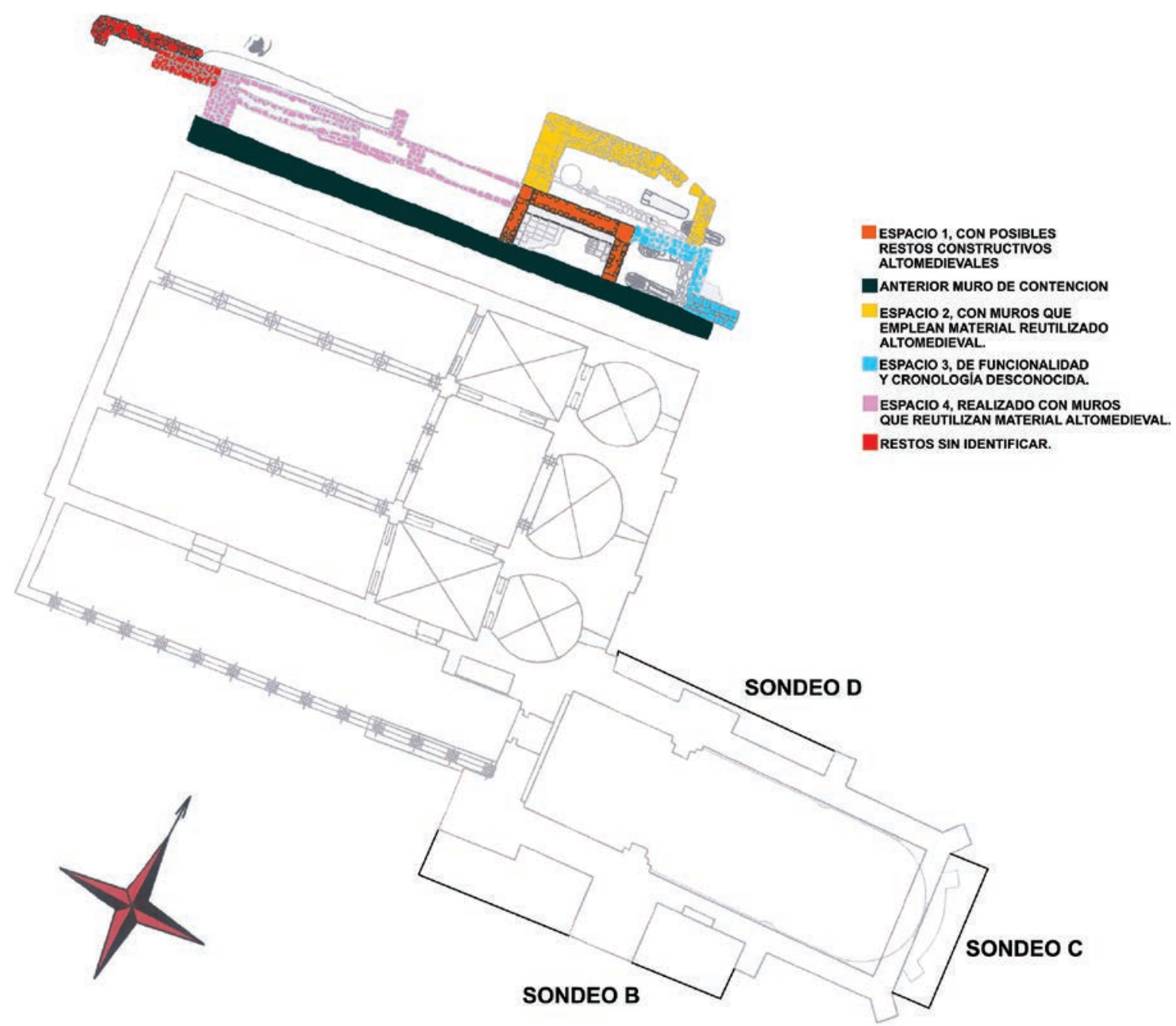

Fig. 3 San Miguel de Escalada: planta general de los restos del sector 500 (aparecidos al norte de la iglesia monástica consagrada el año 913), según Campomanes - San Román (2006, Modificado), según A.M MARTÍNEZ TEJERA (2008-2009) inédito: T. II, plano 4. Los 'RESTOS SIN IDENTIFICAR' (en color rojo) son los que se han propuesto como pertenecientes a una cerca o muro monástico.

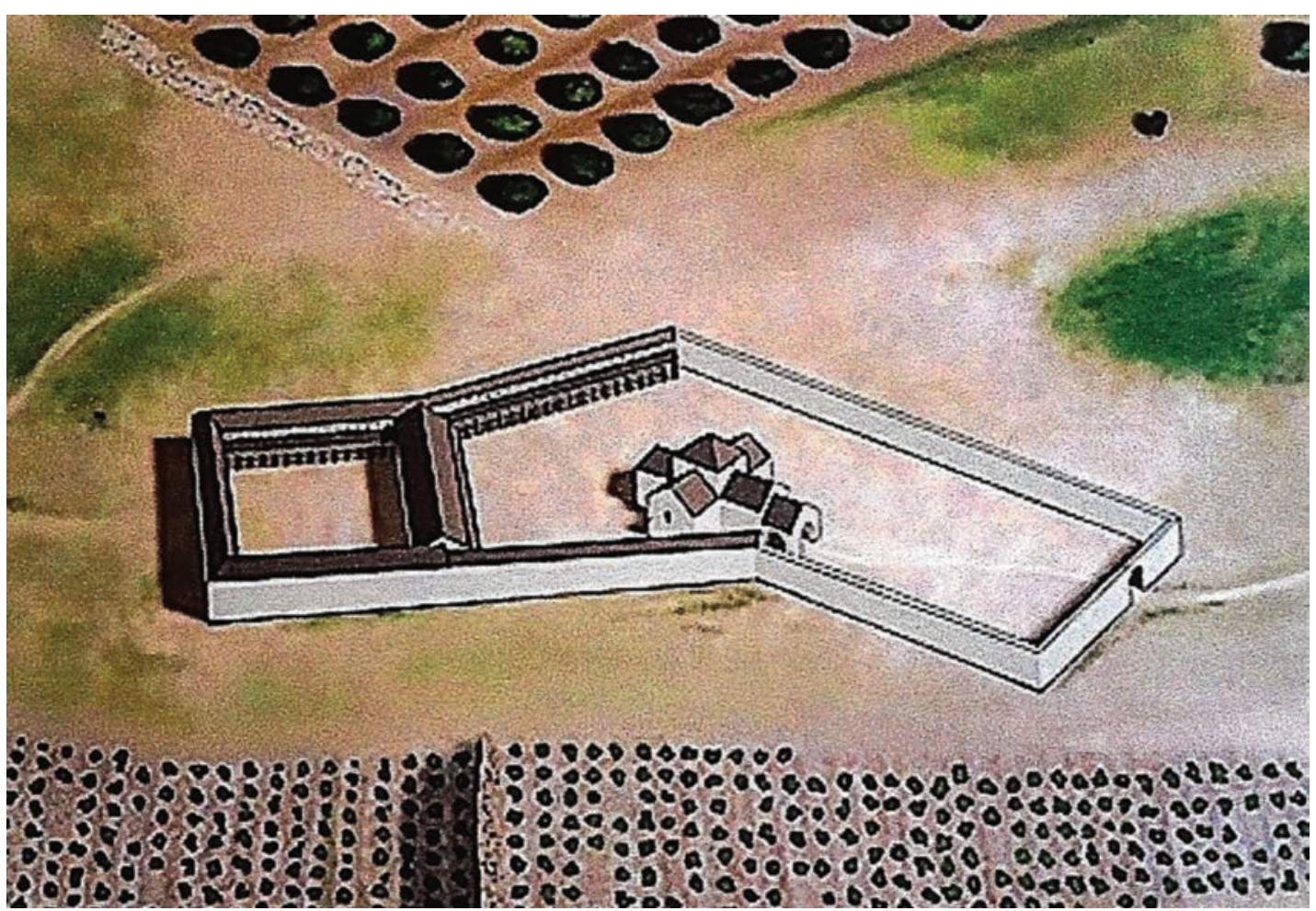

Fig.4 Restitución del paisaje del Monasterio de Santa María de Melque (@ Ilustración G. Corbacho sobre idea de Barroso, Carrobles y Morín, 2015). 


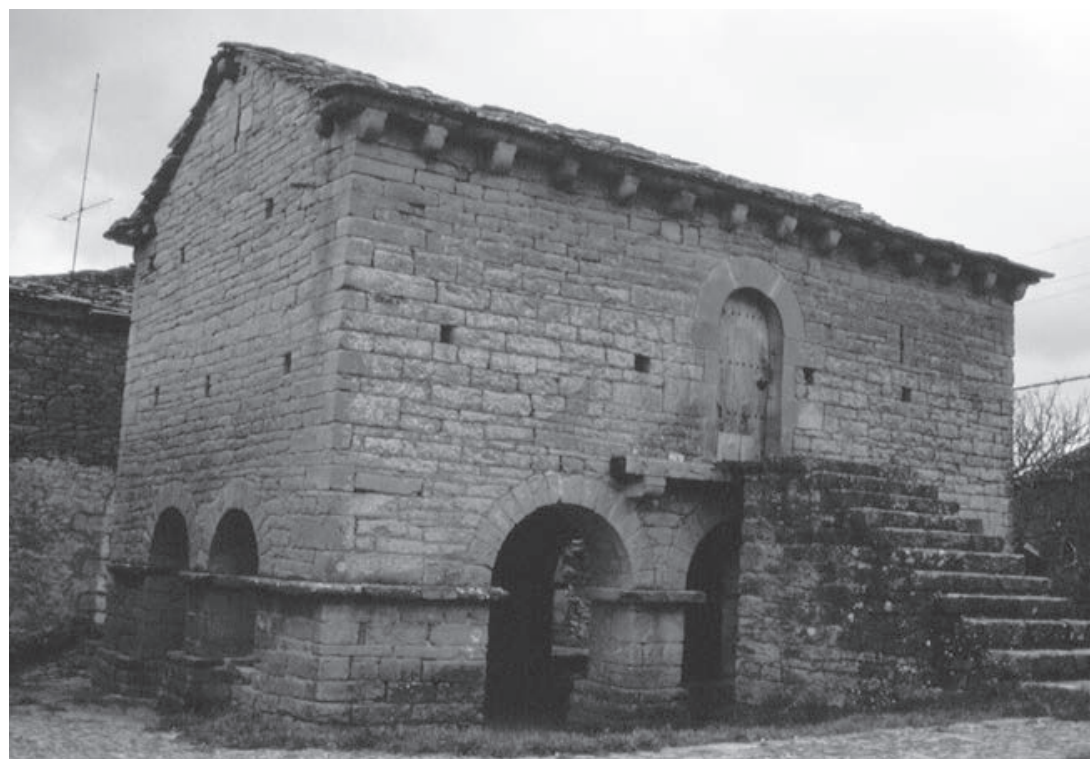

Fig. 5 El horreum de Iratxeta (Navarra), es una construcción singular a la que se le otorga una amplia cronologia (ss. VII-XII). No obstante, refleja la estructura que, en base a los textos, poseian estos edificios para el almacenaje en la alta Edad Media: una construcción sólida, con una escasa ventilación (mediante estrechas fenestrae, según San Isidoro) y dos alturas, dedicándose el cuerpo superior al almacenamiento. Un edificio tipo repostaria (@Artemio M. Martínez Tejera). c) Yapenas sabemos nada, desde la perspectiva arqueológica, de un espacio paradójicamente bastante bien conocido por las fuentes: me refiero al huerto cenobítico (hortus / hortulus / pomerio) ${ }^{48}$. Eso sí, sabemos que su cuidado era responsabilidad del hortelano (hortulanum), al que también correspondía - según señala san Isidoro - proteger y custodiar las colmenas de abejas, la selección de semillas y estar al tanto de cuándo y qué debía plantarse en el huerto: y conocemos, gracias a los estudios de Justiniano Rodríguez el nombre del hortelano de un monasterio altomedieval, el del cenobio leonés de Abellar (santos Cosme y Damián), que en el 977 era Velite ${ }^{49}$.

El huerto (hortus, hortulus o "jardín de la cocina") como espacio dedicado al cultivo de hortalizas (oleribus), legumbres, etc., y destinado a garantizar y las necesidades alimenticias de la comunidad, fue un espacio fundamental en el organigrama cenobítico altomedieval, al menos en el de San Pedro de Montes, donde Genadio y sus compañeros no solo construyeron edificios, también plantaron viñas y pomares y dispusieron huertas y todo lo necesario para el monasterio (aedificia instruxi, uineas et pode un único acceso no cabe duda, pero si sobre la cerca, ya que esta pudo no hacer falta ${ }^{44}$.

Y para garantizar al máximo esa protección, el monasterio debía buscar la autosuficiencia y minimizar el contacto con el exterior, por eso se dotó de una serie de espacios, entre otros los destinados a albergar distintas actividades productivas y los espacios con funciones de almacenaje y transformación, que son por los que vamos a comenzar.

\subsubsection{ESPACIOS PARA LA PRODUCCIÓN, TRANSFORMACIÓN Y ALMACENAJE}

a) Sabemos que los monasterios hispanos del s. VII contaron con un ámbito conocido como cellarium o cella, la despensa o almacén cenobítico, que se encontraba a cargo del cellarius, al que incumbían además otras muchas actividades ${ }^{45}$. ¿Y en la alta Edad Media? La única información la transmite la Regula Communis en su cap. VI, que indica como a cargo del cellarius se encontraba la despensa y la alimentación de los niños, enfermos y peregrinos ${ }^{46}$.

b) Nada sabemos respecto a la materialización y localización de los espacios destinados al almacenaje de los instrumentos de trabajo de los monjes. Tan solo que en su capítulo XVI la 'regla de los santos Pablo y Esteban', denomina a esta estancia artificum oficiniis; en ocasiones, un armarium comunitario ${ }^{47}$. mares plantavi, terras de scalido eieci, horta et omnia quae ad usum monasterii pertinent, imposui) ${ }^{50}$; un espacio que en los primeros momentos poco o nada tuvo de ornamental, pues en un principio no fue sino la continuación de aquél pequeño hortus romano que se encontraba al cuidado de la madrey en el que se cultivaban las hortalizas para el consumo familiar ${ }^{51}$.

d) Otra dependencia, estancia o edificio para el almacenaje, en este caso principalmente de grano, fue el horreum, que san Isidoro sitúa bajo la responsabilidad del cellario; un espacio, al que también denominará apotheca y granaria, del tipo repostaria o reconditori, aquel en el que los hombres almacenaban los frutos recolectados ${ }^{52}$. ¿Un edificio aislado unitario, compartimentado, o una dependencia? Aunque hasta el momento no ha sido posible identificar con total seguridad, y desde el punto de vista material, dependencias de este tipo en los conjuntos cenobíticos altomedievales, traemos a colación el único edificio, y de dudosa cronología altomedieval (ss. VII-XI), que ha sido identificado con un horreum, aunque no monástico, y que se encuentra en la de planta rectangular $(5,67 \times 8,44 \mathrm{~m})$, presenta un aparejo que tiende al sillarejo, siendo únicamente en los anguli, en el punto de encuentro de dos paredes, donde se refuerza con sillares dispuestos en hiladas de distinto grosor, característica constructiva que comparte con los edificios altomedievales astur-leoneses. Un aparejo que recuerda el empleado en pequeña localidad navarra de Iratxeta ${ }^{53}$ (fig. 5). El edificio,

${ }^{44}$ Pues ya en el s. VII el cenobio ejercía, en si mismo, de 'fortaleza' y reflejaba la solidez de la observancia y defendía al monje del Diablo, su principal enemigo, que rondaba a su alrededor "como león rugiente con las fauces abiertas queriendo devorarnos": San Leandro, San Fructuoso, op. cit. (n. 21), p. 91.

${ }^{45}$ A.M. MARTÍNEZ TEJERA, op. cit. (n. 3), T. I, p. 317-321; ID., op. cit. (n. 1), p. 25-26.

${ }^{46}$ A.M. MARTÍNEZ TEJERA, op. cit. (n. 3), T. I, p. 318, nota no 1470.

${ }^{47}$ Ibidem, p. 322-323; A.M. MARTÍNEZ TEJERA, op. cit. (n. 1), p. 26.

${ }^{48}$ Sobre este espacio en los monasterios hispanos tardoantiguos y altomedievales: A.M. MARTÍNEZ TEJERA, op. cit. (n. 40); ID., op. cit. (n. 1), p. 26-27.

49 J. RODRÍGUEZ FERNÁNDEZ, La monarquía leonesa. De García I a Vermudo III (910-1037), in El Reino de León en la Alta Edad Media III ("La monarquía astur-leonesa. De Pelayo a Alfonso VI, 718-1109"), León, 1995, p. 129-413, especialmente p. 349.

${ }^{50}$ Fr. J. HERREZUELO, Historia de San Pedro de Montes, Archivo Diocesano de Astorga, Signatura R.2., f. 116-117, (1818) inédito.

${ }^{51}$ A.M. MARTÍNEZ TEJERA, op. cit. (n. 40), p. 121 y 153.

${ }^{52}$ Etimologías, op. cit. (n. 2), libro XV, 6: De repositoriis, T. II, p. 242.

53 A.M. MARTÍNEZ TEJERA, op. cit. (n. 1), p. 27. 


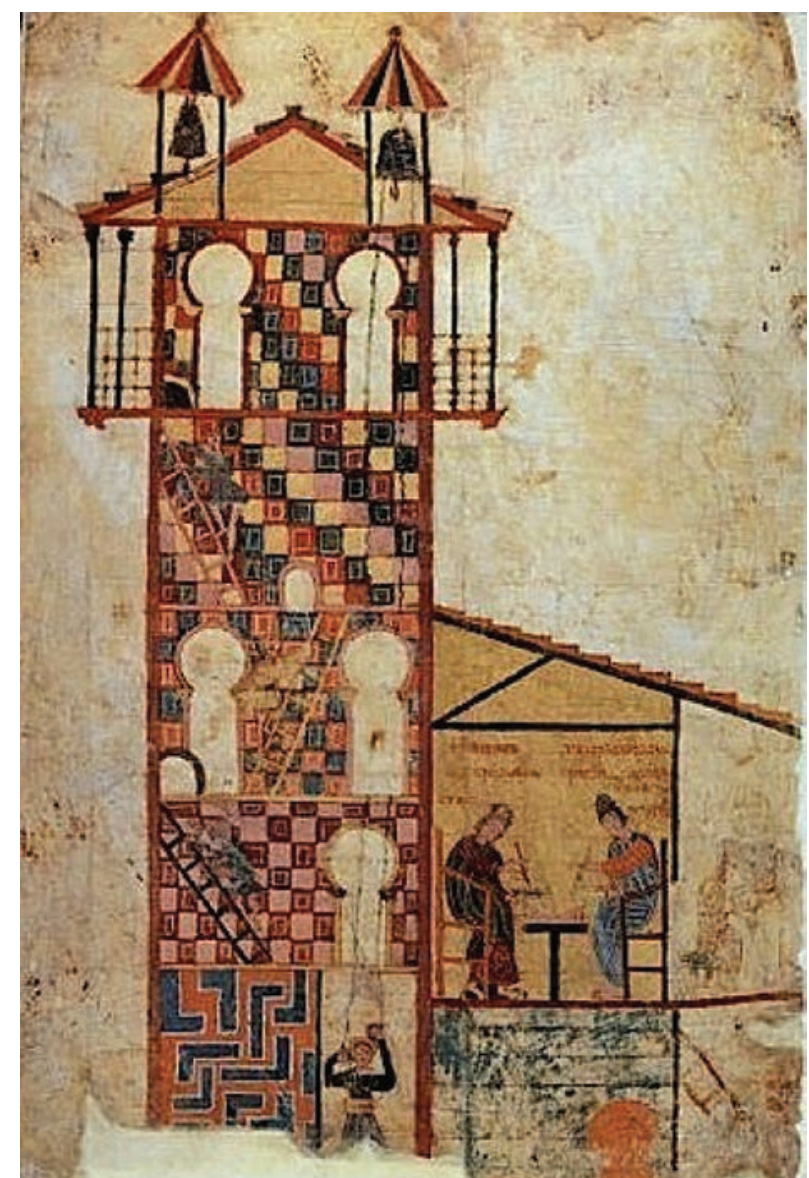

Fig. 6 Miniatura del 'Beato de Tábara' (Archivo Histórico Nacional cod. 1097b, Fol. 167) que representa la turre tabarense alta et lapidea y el scriptorium adosado a ella.

otros edificios eclesiales de la zona del Gállego de la misma cronología: San Pedro de Larrade, San Juan de Busa, etc.

e) Y también contaron los monasterios hispanos altomedievales con un molino o pistrinum para moler el grano, o al menos así se desprende del cap. VIII de la Regula Communis, que, además, exime a los ancianos de trabajar en él54.

f) Pero que duda cabe que una de las dependencias más 'conocidas' de los monasterios hispanos es el obrador o scriptorium representado en una miniatura del beato de Tábara ${ }^{55}$. No conocemos ningún resto, pero conservamos la imagen de uno, el scriptorium o scrinium del monasterio de Tábara, en la prov. de Zamora ${ }^{56}$ (fig. 6). Éste se localiza en una estancia del piso superior de un edificio adosado a la derecha de la torre; posee techumbre inclinada, a una sola vertiente, y cubierta de tejas, es decir, era lo que los documentos del s. X denominaron edificios teliatos, y se articula en dos alturas, con dos estancias cada una; concretamente aquella en la que trabajaban los escribas o copistas Emeterio y Señor parece ser que también contaba con armadura de madera. En la otra estancia del piso superior un personaje se afana en el proceso de preparación del pergamino y, tal vez, en poner a punto las tablas para la encuadernación del manuscrito. Bajo la habitación de trabajo aparece una entrada, esbozada por un arco de herradura, que no permitía el acceso directo al

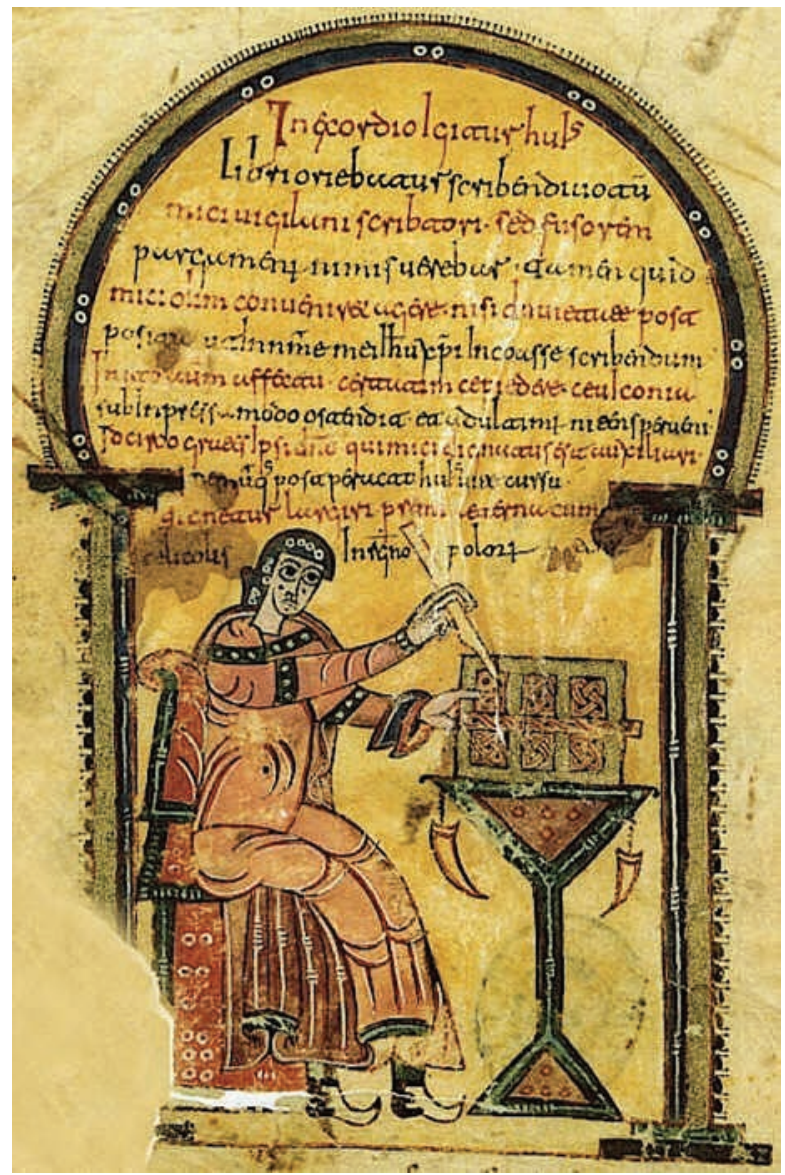

Fig. 7 Códice Vigiliano o Albeldense: Vigila en su scriptorium (Real Biblioteca del Monasterio de San Loenzo de El Escorial, Madrid, Fol. XXIIv)

scriptorium ya que para alcanzar la planta superior se necesitaba de una escalera de mano o scala como la que aparece apenas esbozada en la estancia de la planta baja adosada a la torre. Un sistema de comunicación, por trampillas en el suelo, que se repetirá en la torre.

¿Realidad o ficción? Dudamos que la torre representada hiciera las veces de bibliotheca, como se ha sugerido, pues no encontramos argumentos para tal ubicación en un monasterio hispano. Una localización muy distinta a la que se presenta en el plano de otro conjunto cenobítico altomedieval no hispano (en este caso anterior, de la primera mitad del s. IX) como es el de St. Gall, en el que la bibliotheca se encuentra en el piso superior del edificio que aparece adosado al transepto de la iglesia, mientras que el scriptorium se encuentra en la planta baja, comunicándose con el transepto ${ }^{57}$. La existencia de estos espacios arquitectónicos para la copia o realización de códices en los cenobios altomedievales hispanos de San Pedro de Montes (León), San Millán y Albelda (La Rioja); S. Pedro de Cardeña, 924 (Burgos), etc, está acreditada por las fuentes escritas ${ }^{58}$. Otra representación de un scriptorium la encontramos en el Codex Albeldense, concretamente en el folio que presenta, según la leyenda que acompaña la imagen, al monje Vigila en el scriptorium (fig. 7). Pero en realidad la imagen tan solo muestra, enmarcada por un arco

${ }^{54}$ San Leandro, San Fructuoso, op. cit. (n. 21), p. 186.

55 A.M. MARTÍNEZ TEJERA, op. cit. (n. 1), p. 27-28.

${ }^{56}$ F. GALTIER MARTÍ, O turre Tabarense alta et lapidea... Un saggio d'iconografia castellologica sulla miniatura della Spagna cristiana del secolo X, in Archeologia e arte nella Spagna tardoromana, visigota e mozarabica, XXXIV Corso di Cultura sull'arte ravennate e bizantina, Ravenna, 1987, p. 253-289; F. REGUERAS GRANDE - H. GARCÍA-ARÁEZ FERRER, Scriptorium. Tábara visigoda y mozárabe, Salamanca, 2001.

57 A.M. MARTÍNEZ TEJERA, op. cit. (n. 1), p. 28, n. 48.

${ }^{8}$ ID., op. cit. (n. 3), T. I, p. 332. 
ultrasemicircular, la figura del monje Vigila sentado trabajando sobre una mesa o escritorio. ¿Fue el scriptorium de los ss. IX-X una estancia o un elemento mueble?

2.1.2 ESPACIOS PARA LA ASISTENCIA Y EL ALOJAMIENTO

g) Y también contaron los cenobios altomedievales hispanos con espacios para la asistencia, con espacios que servían de alojamiento y ofrecían asistencia al peregrino, viajero y visitantes, y, obviamente, para el uso exclusivo de los cenobitas, tal y como sucedió en los siglo precedentes ${ }^{59}$. Pero tampoco conocemos su localización ni organización. No obstante, sabemos que a finales del s. VII en el canon III del tercer concilio de Zaragoza (a. 691), se prohíbe a los seglares hospedarse en el interior del recinto monástico - excepto a los de vida muy probada, pobres o arruinados y siempre a juicio

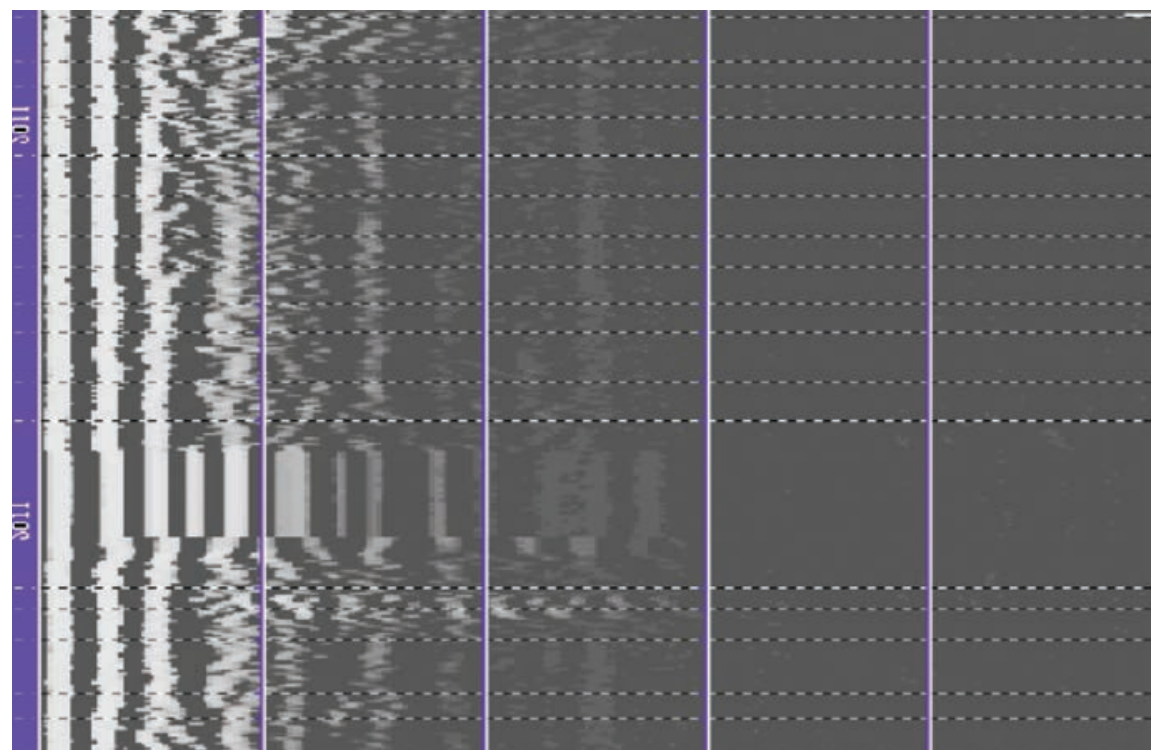

Fig. 8 Toma de datos con geo-radar en San Miguel de Escalada, Perfil 3 (lado sur del edificio altomedieval): A.M. MARTÍNEZ TEJERA (2008-2009) inédito.

Por lo que sabemos hasta el momento, las celdas monásticas hispanas altomedievales pudieron ser de uso individual pero espacialmente formaban parte de una estructura o edificio más amplio: esto es lo que al parecer ocurrir en el monasterium de San Miguel de Escalada (circa 913), donde recientes excavaciones arqueológicas has terminado por desvelar una estructura situada al norte de la ecclesia, ya descubierta en los años 8o, que se esta identificando, tal vez apresuradamente, con celdas monásticas ${ }^{65}$.

i) Un espacio penitencial y de castigo existente en los cenobios hispanos altomedievales fue la cella obscura, recogida en los caps. XIV y XV de la Regula Communis a la hora de indicar el lugar al que iban a parar los monjes reincidentes y excomulgados: como ya indicamos en 1997 la 'celda oscura' era estrecha y en ella permanecía el monje seis meses sujeto con grillos de hierro y comiendo una pequeña ración de pan tres veces por semana. Y en una cella obscura sería encerrado durante seis meses - según el pactum - el monje que en ausencia del abad tramase algo contra la regla $^{66}$. Un tipo de celdas un tanto especiales por su carácter (penitencial y de castigo) y de difícil habitabilidad (algunas oscuras y de pequeño tamaño), vinculadas a ambientes que apuntan ciertos atisbos de eremitismo restrictivo, e incluso de individualismo abacial.

j) Resulta tremendamente aventurado, desde los datos ofrecidos por los textos, concretar si el monasterio altomedieval hispano contó con un 'claustro' como un órgano arquitectónico distribuidor antes del siglo $\mathrm{X}^{67}$, ni siquiera en los territorios de la 'Marca hispánica', dónde hasta la segunda mitad de esa centuria el monacato parece seguir - indicó Gerardo Boto hace ya unos años - las pautas hispánicas ${ }^{68}$. Aunque parece presentar alguna singularidad, como que nos hemos de verlas ligadas a ambientes con un fuerte individualista, tanto en su concepción como en su disciplina.

59 ID., op. cit. (n. 1), p. 28 y ss.

${ }^{60}$ J. VIVES GATELL - T. MARÍN - G. MARTÍNEZ DÍEZ, op. cit. (n. 38): p. 473-476; R. PUERTAS TRICAS, op. cit. (n. 6), p. 127.

${ }^{61}$ San Leandro, San Fructuoso, op. cit. (n. 21), p. 188.

${ }^{62}$ A.M. MARTÍNEZ TEJERA, op. cit. (n. 8), p. 121.

${ }_{3}$ ID., op. cit. (n. 1), p. 29

${ }^{64}$ R. BRAUNFELS, La Arquitectura monacal en Occidente, Barcelona, 1975, p. 300.

${ }_{55}^{6 . M . M . ~ M A R T I ́ N E Z ~ T E J E R A, ~ o p . ~ c i t . ~(n . ~ 13), ~ p . ~ 45-47 . ~}$

${ }^{66}$ ID., op. cit. (n. 8), p. 122.

${ }^{67}$ Sobre este espacio en los cenobios hispanos tardoantiguos: ID., op. cit. (n. 1), p. 30-31.

${ }^{68}$ G. BOTO VARELA, Topografía de los monasterios de la marca de Hispania (ca.80o - ca.103o), in Monjes y Monasterios hispanos en la Alta Edad Media, XIX Seminario sobre Historia del Monacato, Aguilar de Campooo, 2006, p. 147-203. 
las iglesias carecen de canceles o que, vistos los ejemplos, nos parece que los edificios monásticos altomedievales de la Marca Hispánica hasta la segunda mitad del s. X solían ser muy escasos, pero polifuncionales y de dos pisos.

Pero volviendo al tema de la existencia o no del claustro en los monasterios altomedievales hispanos, personalmente somos de la opinión de que los monasterios altomedievales hispanos tuvieron más 'patios' que 'claustros monumentalizados' 69 . Por lo que respecta al monasterio leonés de San Miguel de Escalada las dudas se disiparán, muy posiblemente, en cuanto se efectúen excavaciones en ese espacio, ya que el geo-radar ha confirmado la existencia de restos constructivos a gran profundidad y muros verticales bajo el subsuelo, tanto en el espacio que se abre ante el pórtico como al oeste $7^{70}$ (fig. 8).

k) Otro espacio cenobítico era el destinado al descanso, que encontramos en los textos con los términos cubiculum, dormientum locum y durmiturium. Como ya hemos dejado dicho en otras ocasiones ${ }^{71}$, san Isidoro y san Fructuoso aconsejan la existencia de un único dormitorio, considerando además el primero la conveniencia de que en dicho lugar, en el dormientium locum, luciese, llegada la noche, una lámpara. Eso si, el primero un único dormitorio siempre y cuando fuera posible y el segundo en un único dormitorio, sin excepción, y con las camas o lechos a un codo de distancia -al menos- unas de otras ${ }^{72}$.

¿Qué sucede en la alta Edad Media? La conveniencia de un único dormitorio seguirá prevaleciendo en las normativas monásticas a partir de s. VII, aunque también se percibe cierta flexibilidad, de manera que la "Regla de los santos Pablo y Esteban”, (en su cap. XI) permitirá a los monjes dormir la siesta en tiempos de recolección, pero todos juntos, cada uno en su lecho, en un mismo lugar o a lo máximo distribuidos en dos grupos ${ }^{73}$. Y al menos dos dormitorios encontramos en los monasterios dúplices altomedievales regidos por la Regula Communis ${ }^{74}$.

1) Otra de las dependencias de la que no conocemos nada bajo la cota 0 es de la enfermería de los monjes, el locum aegrotantium o cella languentium. Las reglas hispanas del s. VII indican que debía estar apartada de la basílica y de las celdas de los monjes con el fin de salvaguardar a los enfermos de ruidos y voces ${ }^{75}$, mientras que la Regula Communis únicamente se limita a señalar, en su cap. VII, la existencia de una casa en donde residían los enfermos (domus infirmorum), cuyo cuidado estaba encomendado a un único individuo apto para ello ${ }^{76}$. Ninguna noticia proporcionan los textos altomedievales; tan solo conocemos la existencia de una Domus infirmorum altomedieval, la de San Pedro de Montes, que fue restaurada en $1164^{77}$.

m) Los alimentos los tomaban los cenobitas en una estancia que los textos tardoantiguos denominaron refectorium / triclinium / cenaculum y coenaculum ${ }^{78}$. ¿Conservamos restos de algún refectorio cenobítico en territorios cristianos? Desafortunadamente, la respuesta es no.

n) Y también contaron los monasterios hispanos altomedievales con espacios destinados a la enseñanza, el aprendizaje y al estudio, aunque no conocemos nada sobre su localización y definición arquitectónica. Recordemos que en los cenobios sirios de los ss. IV-VI, esta escuela podía encontrarse integrada en el edificio porticado que aparece en los recintos de importantes $\operatorname{cenobios}^{79}$ : ¿sucedería lo mismo en Hispania?

ñ) Y lo mismo ocurre con la bibliotheca, que según san Isidoro era el lugar o armario (théke) en el que guardar los libros (biblos); lugar en el que se guardaban los libros (en griego pygiscos $)^{80}$ que sería una dependencia o elemento de necesaria existencia en los monasterios benedictinos, pues al inicio de la Cuaresma se entregaba a cada monje "un libro de la biblioteca" ${ }^{\text {. }}$. El que se tratase de una estancia propiamente dicha o de un armario - en ocasiones de fábrica, a modo de una hornacina abierta en el muro, como ocurre en varios cenobios occidentales y sirios -, dependería del número de libros custodiados ${ }^{82}$.

Hace ya muchos años, en 1976, que Díaz y Díaz mostró que infinidad de donaciones altomedievales tuvieron como uno de sus principales protagonistas a los $\operatorname{libros}^{8_{3}}$, lo que indirectamente sugiere la existencia de espacios concretos para su custodia - en ocasiones bastante amplios - en un buen número de cenobios peninsulares. Y cuando estos no podían 'costearse' una, los libros circulaban entre diversos monasterios. Así surgió la primera 'bibioteca de uso compar-

69 J. LÓPEZ QUIROGA - A.M. MARTÍNEZ TEJERA, El espacio cultual cristiano y su relación con el territorium en Hispania (siglos V-VII): los casos de El Bovalar, Recopolis, Algezares y Tolmo de Minateda, in El primer cristianismo en el Mediterráneo Occidental. Homenaje a Pere de Palol, VI Seminario Internacional de Historia (24-25 de noviembre de 2006, Museo Arqueológico de Elda-Universidad de Alicante), en prensa.

$7^{\circ}$ A.M. MARTíNEZ TEJERA, Proyecto Científico y Estudio Histórico-Artístico del monasterio de San Miguel de Escalada (Gradefes, León), 4 Tomos, Valladolid, p. 12-13.

${ }^{71}$ ID., op. cit. (n. 8), p. 121; ID., op. cit. (n. 1), p. 31.

${ }^{72}$ San Leandro, San Fructuoso, op. cit. (n. 21), p. 110-111 y 138.

${ }^{73}$ A.M. MARTÍNEZ TEJERA, op. cit. (n. 1), p. 31.

${ }^{74}$ San Leandro, San Fructuoso, op. cit. (n. 21), p. 200.

75 A.M. MARTÍNEZ TEJERA, op. cit. (n. 1), p. 31.

${ }^{76}$ San Leandro, San Fructuoso, op. cit. (n. 21), p. 184.

77 A. QUINTANA PRIETO, Tumbo Viejo de San Pedro de Montes, León, 1971, doc. no 200, p. 320-323.

$7^{78}$ A.M. MARTÍNEZ TEJERA, op. cit. (n. 1), p. 31-32.

${ }^{79}$ Ibidem, p. 32.

${ }^{80}$ Etimologías, op. cit. (n. 2), libro XV.5, T. II, p. 240-241; A.M. MARTíNEZ TEJERA, op. cit. (n. 1), p. 32-33.

${ }^{81}$ G.M. COLOMBÁS, San Benito. Su vida y su regla, Madrid, 1957, cap. XLVIII.

${ }^{82}$ De hecho, el monasterio zaragozano de Santa Engracia contaba, en la Antigüedad Tardía, con unos 450 códices distribuidos en 14 ó 16 armarios; y en la misma época el monasterio calabrés de Vivarium (fundado por Casiodoro hacia el a. 550) contaba, como mínimo, con 8 armarios para la custodia de códices: A.M. MARTÍNEZ TEJERA, op. cit. (n. 1), p. 32, n. 77 y 78. En el occidente europeo altomedieval (ss. IX y X) sabemos que monasterios como Bobbio (Italia) y Lorsch (Alemania) contaban con bibliotecas que albergaban en torno a 6oo volúmenes.

${ }^{83}$ M.C. DÍAZ Y DÍAZ, De Isidoro al siglo XI. Ocho estudios sobre la vida literaria peninsular, 3, Barcelona, 1976, p. 177-178. 


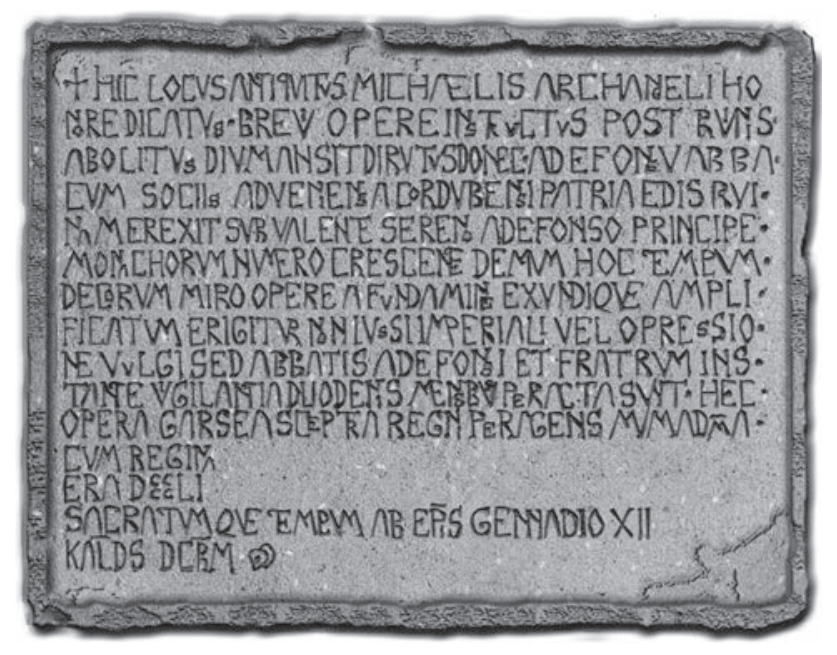

Fig. 9 Reconstrucción hipotética del desaparecido 'Monumento de Consagración' de la iglesia de San Miguel de Escalada (el epigrafe original, desde la década de los años 60-70 del s. XX, se encuentra en paradero desconocido). Este es el unico testimonio material que, hasta ahora, vincula la iglesia de San Miguel de Escalada con un ambiente monástico (texto, (C)Artemio M. Martinez Tejera; diseño, (C) Castor García Ovies).

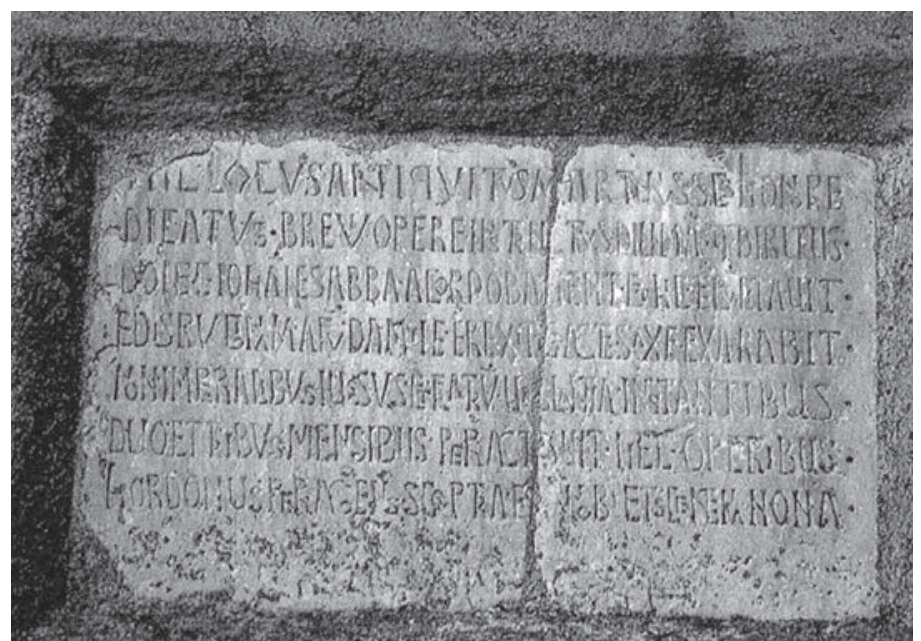

Fig. 10 Monumenta aedificationis del monasterio altomedieval de San Martín de Castañeda (Zamora) que habla de un abad de nombre Juan y procedente de Córdoba que hacia el año 921 construyó, en cinco meses, el monasterio de San Martin (@) Ángela Crespo Espinel). La de San Martín de Castañeda es una de las muchas 'aldeas espirituales' altomedievales hispanas de las que solo conocemos su existencia por las fuentes escritas y los restos de una iglesia.

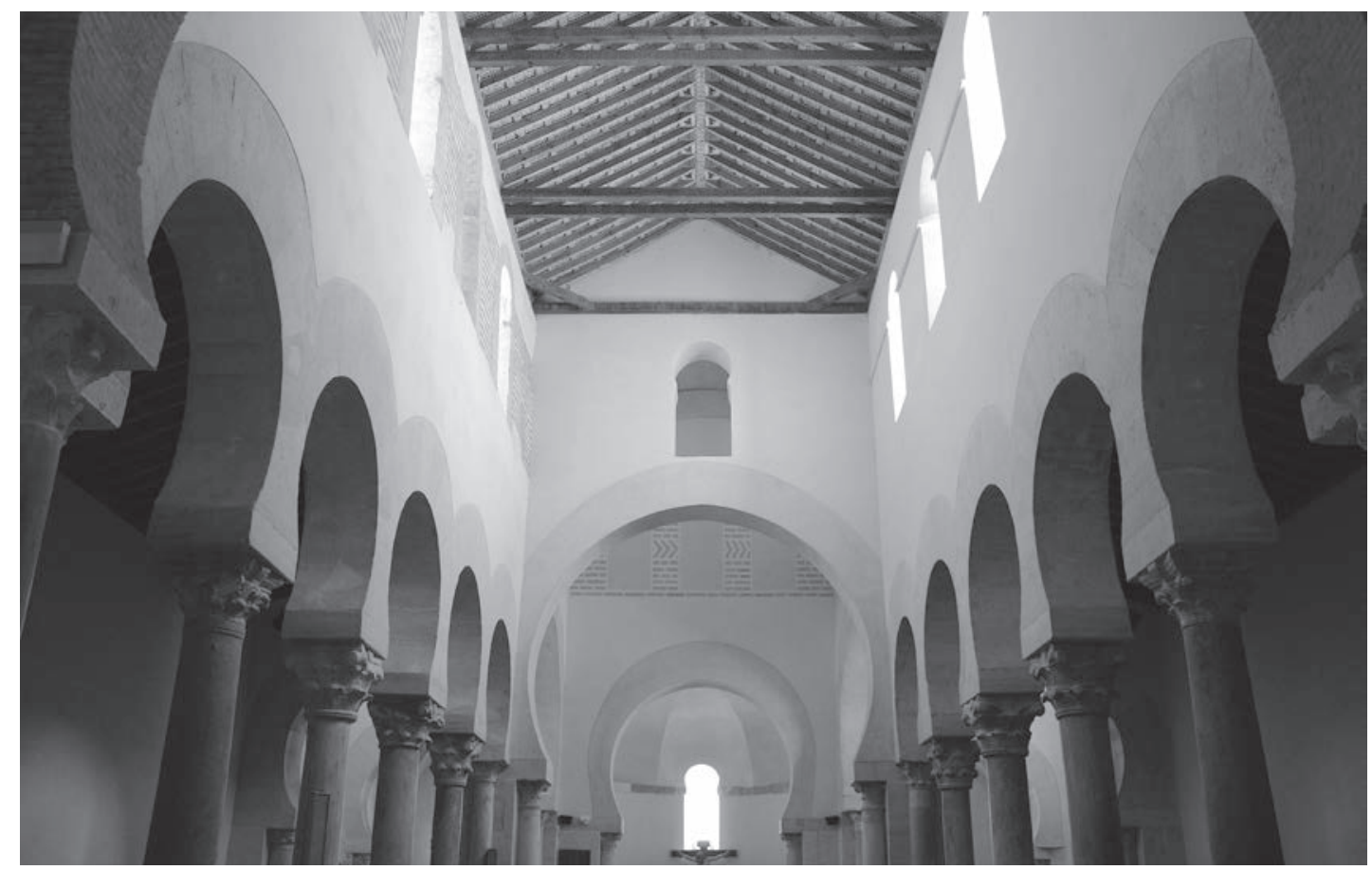

Fig. 11 Interior de la iglesia de San Cebrián de Mazote (Valladolid): un edificio del s. X de planta basilical dotado de tres naves cubiertas con madera, que fue prácticamente destruido en su totalidad durante la Guerra Civil española (1936-1939). En este monasterio, fundado por monjes procedentes de San Martín de Castañeda, aparecen por vez primera los 'capiteles de la serie leonesa', entre los años 920-940 (C) Angela Crespo Espinel).

tido', la que San Genadio hizo circular entre sus fundaciones, tal y como señala en su Testamentum ${ }^{84}$.

o) Y dejamos para el final la única dependencia de los monasterios altomedievales que habría quedado en pie, el edificio cultual, la basilica, oratorium, ecclesia o templum: la iglesia ${ }^{85}$. Y se las considera monásticas porque hay alguna inscripción o epígrafe que así lo indica (en el caso de los cenobios de San Miguel de Escalada o San Martín de Castañeda, este último en la provincia de Zamora) ${ }^{86}$ (figs. 9-10), tal y como sucede en Oriente desde el s. VI al menos, o bien porque hay documentos que así lo indican, como sucede con San Salvador de Valdediós (Asturias) ${ }^{87}$, Peñalba de Santiago (León), San Cebrián de Mazote (Valladolid) (fig. 11), etc., Por lo que sabemos hasta ahora, las iglesias cenobíticas hispanas de los ss. IX-X contaron preferentemente con tres naves, tal y como sucedió en la Antigüedad Tardía; con doble entrada, una para que los monjes accedieran desde sus dependencias, y otro para los fieles (los ejemplos son muchos en los ss. IX-

\footnotetext{
${ }^{{ }_{4}} \mathrm{Fr}$. J. HERREZUELO, op. cit. (n. 50), f. 118-119.

${ }^{85}$ Sobre la terminología aplicada al edificio cultual monástico en Hispania: A.M. MARTÍNEZ TEJERA op. cit. (n. 3), T. II, p. 79 y ss.

${ }^{86}$ ID., Dedicaciones, consagraciones y Monumenta consecrationis (siglos VI-XII): testimonios epigráficos altomedievales en los antiguos reinos de Asturias y León, in Brigecio, 6, 1996, p. 77-102, especialmente p. 86 y ss.

${ }^{87}$ M. NÚÑEZ RODRÍGUEZ, San Salvador de Valdediós o la fábrica sencilla de una arquitectura admirable, Guías del Patrimonio Artístico Asturiano no 6, Oviedo, 1991.
} 


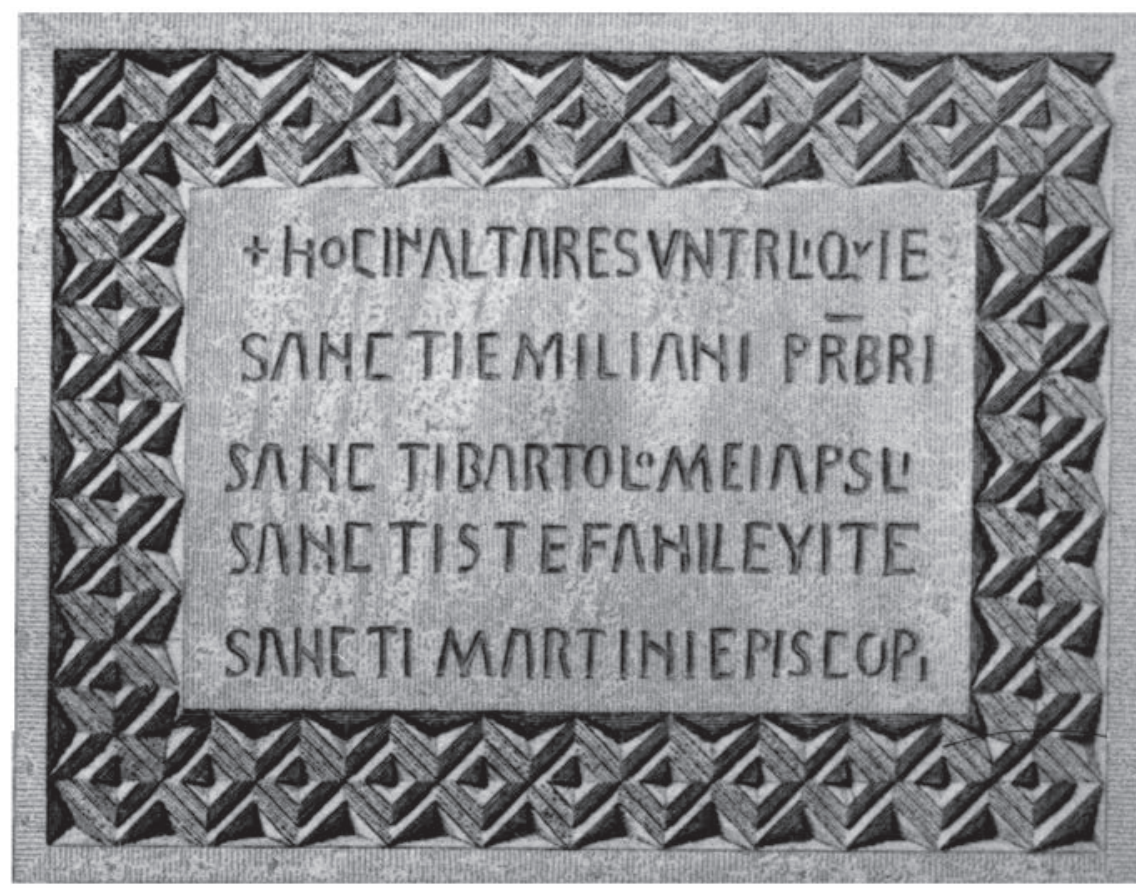

Fig. 12 Arae norte de San Miguel de Escalada (@) Monumentos Arquitectónicos de España, 1870), con el íncipit: + HOC IN ALTARE..., en A.M. MARTINEZ TEJERA, 2005.

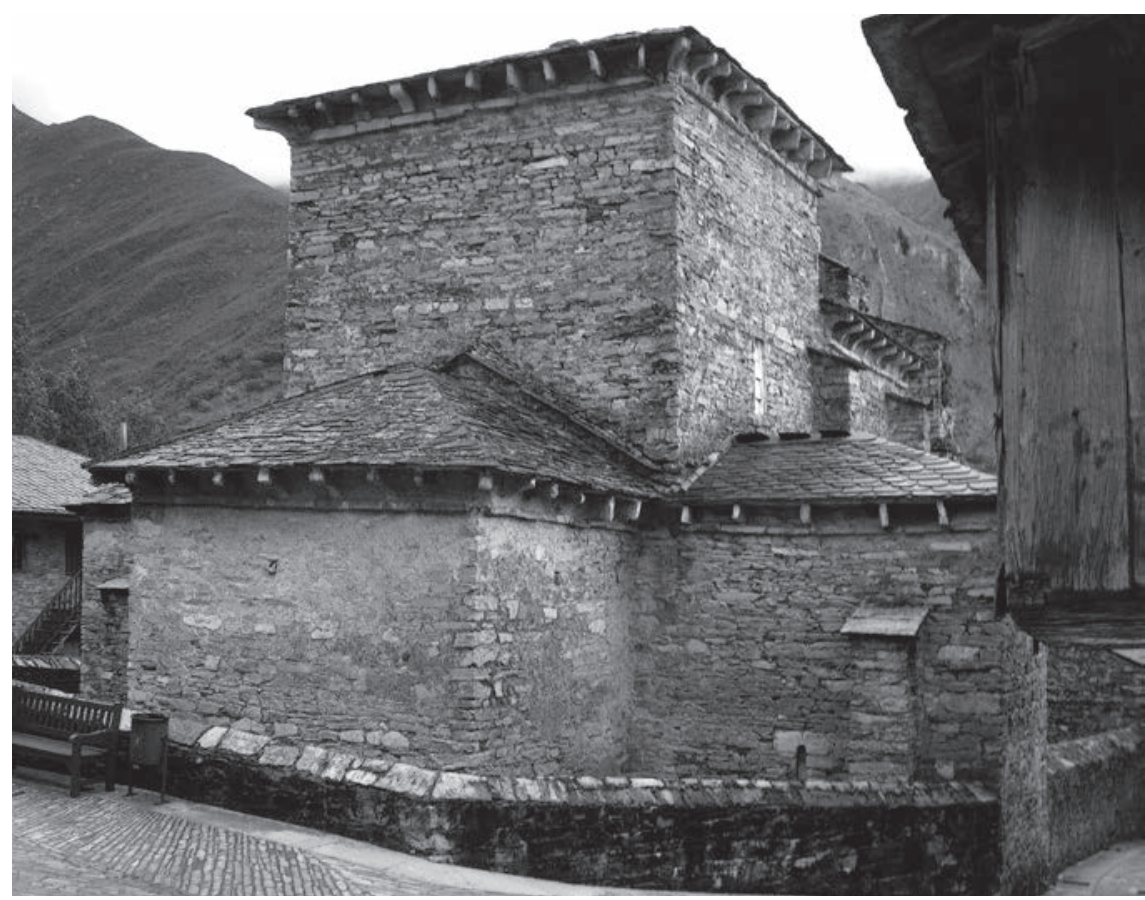

Fig. 13 Exterior de la cabecera de la iglesia de Peñalba de Santiago (León): siendo obispo fundó San Genadio el 'monasterium' de Peñalba, que fue consagrado por el obispo Salomón el año 937. Probablemente fue en ese momento cuando Peñalba se convirtió en un coenobium y cuando fue enterrado en su interior su fundador (C) Ángela Crespo Espinel).
X: San Salvador de Valdediós, San Miguel de Escalada, Peñalba de Santiago, San Cebrián de Mazote) y con un coro o transepto destinado a los monjes. ¿Y con uno o varios altares? ¿Y con una o varias celdas/sacristías?

Las respuestas a estas cuestiones desde la Arqueología siguen sin responder de manera precisa; desde la epigrafía, y teniendo en cuenta el caso de San Miguel de Escalada (de sus tres arae solo en una se especifica que es un altar) habría que suponer que los dos restantes son mesas auxiliares ( $i$ los espacios que las acogen, sacristías?); pero la cuestión no es tan sencilla ya que la Arqueología ha refrendado un cambio tipológico únicamente en el espacio absidal central y no es ahí, sino en el espacio absidal norte, dónde se encuentra el epígrafe que habla de 'altar': HOC IN ALTARE SUNT RELIQUIE... ${ }^{88}$ (fig. 12).

Y entendemos, por otra parte, que las de una sola nave servirían a comunidades de reducido tamaño, puede que incluso a ermitaños y solitarios de los alrededores que vieron en la iglesia un lugar de reunión ${ }^{89}$. Esa es la función primigenia que otorgamos al monasterium (iglesia) de Peñalba de Santiago fundado por San Genadio, entre los años de su episcopado (a. 909-920, aprox.), consagrado por el obispo Salomón de Astorga (a. 937) y 'reconsagrado' (a. $1105)^{90}$ (fig. 13). Pero ya posean una o tres naves, en ocasiones las iglesias monásticas hispanas altomedievales presentan un elemento arquitectónico de controvertidos orígenes funcionales, que no arquitectónicos: el contraábside, un espacio litúrgico y funerario de carácter privilegiado $^{91}$ (fig. 14, A-E).

Pero, ¿una o más iglesias? En algunos casos, los monasterios altomedievales surgidos en territorios cristianos tuvieron, al menos, una iglesia comunitaria y un oraculum, una construcción más pequeña - y generalmente con un único acceso, como sucede en Samos o en Celanova - destinada a un culto más restringido al servicio de aquellos monjes que no podían asistir al oficio común o bien al servicio de peregrinos y visitantes, para no interfirieran en el oficio comunitario $0^{92}$. Esto es lo que sucede en San Salvador de Celanova (Ourense), una fundación de San Rosendo de la que únicamente se conserva el oraculum

\footnotetext{
${ }_{88}^{8}$ A.M. MARTÍNEZ TEJERA - J.L SENRA GABRIELY GALÁN, Pervivencia de la liturgia cristiana del mundo antiguo en el medioevo castellano: el triple altar y los altares-nicho de la ermita de Nuestra Señora del Valle (Monasterio de Rodilla, Burgos) y su problemática, in La transición del mundo antiguo al medieval en Castilla, I Curso de Cultura Medieval (Aguilar de Campoo, 1989), Aguilar de Campoo, 1991, p. 104-114. A.M. MARTÍNEZ TEJERA, op. cit. (n. 13), p. 86 y ss. ${ }^{89}$ Sobre la tipología planimétrica de las iglesias hispanas altomedievales: R. PUERTAS TRICAS, Iglesias prerrománicas hispánicas (siglos VIII al XI). Ensayo de tipología arquitectónica, in Mainake, XXI-XXII, Málaga, 1999-2000, p. 139-198.

90 Para el fenómeno de las 'reconsagraciones' de las iglesias hispanas altomedievales: A.M. MARTÍNEZ TEJERA, op. cit. (n. 86), p. 86 y ss.

${ }^{91}$ ID., El contraábside en la 'Arquitectura de Repoblación', in Repoblación y Reconquista, III Curso de Cultura Medieval, Aguilar de Campoo, 1993, p. 149-161; C. GODOY FERNÁNDEZ, A los pies del templo. Espacios litúrgicos en contraposición al altar: una revisión, in Sacralidad y Arqueología, in Antigüedad y Cristianismo, XXI (Murcia), 2004, p. 473-489; J. LÓPEZ QUIROGA - A.M. MARTÍNEZ TEJERA, De corporibus defunctorum: lectura e interpretación histórico-arqueológica del canon XVIII del primer concilio de Braga (a. 561) y su repercusión en la arquitectura hispana de la Antigüedad Tardía, in Morir en el Mediterráneo Medieval, Archaeological Studies on Late Antiquity and Early Medieval Europe (400-100 A. D.), eds. S. Gelichi, J. López Quiroga, P. Perin, Conference Proccedings II; J. LOPEZ QUIROGA - A.M. MARTÍNEZ TEJERA (eds.), Oxford, 2008, p. 151-18o, especialmente, p. 162 y ss.

${ }_{92}^{2}$ A.M. MARTÍNEZ TEJERA, op. cit. (n. 3), T. II, p. 169.
} 

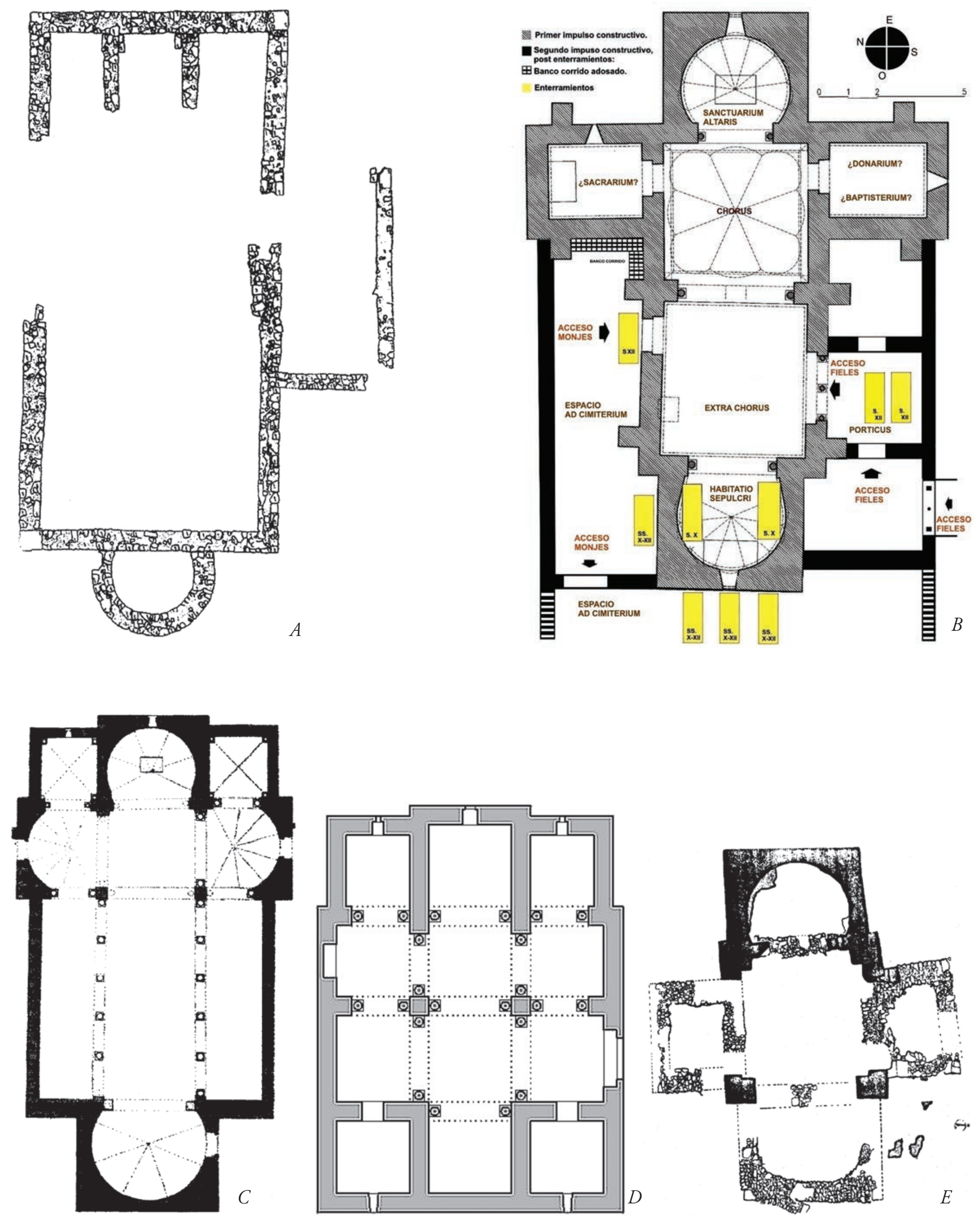

Fig. 14 Algunas iglesias altomedievales con contra-ábsides (ss. IX-X, sin escalas): A. Santa María de Mijangos (prov. de Burgos, s. IX), según J.M. LECANDA, 2002. B. Peñalba de Santiago (prov. de León, c. 909-937), según A.M. MARTÍNEZ TEJERA, 2010b. C. San Cebrián de Mazote (prov. de Valladolid), según GÓMEZ-MORENO 1919. D. Santa María de Lebeña (Cantabria, según). E. Palat de Rey (León), según F. MIGUEL HERNÁNDEZ 1996. 


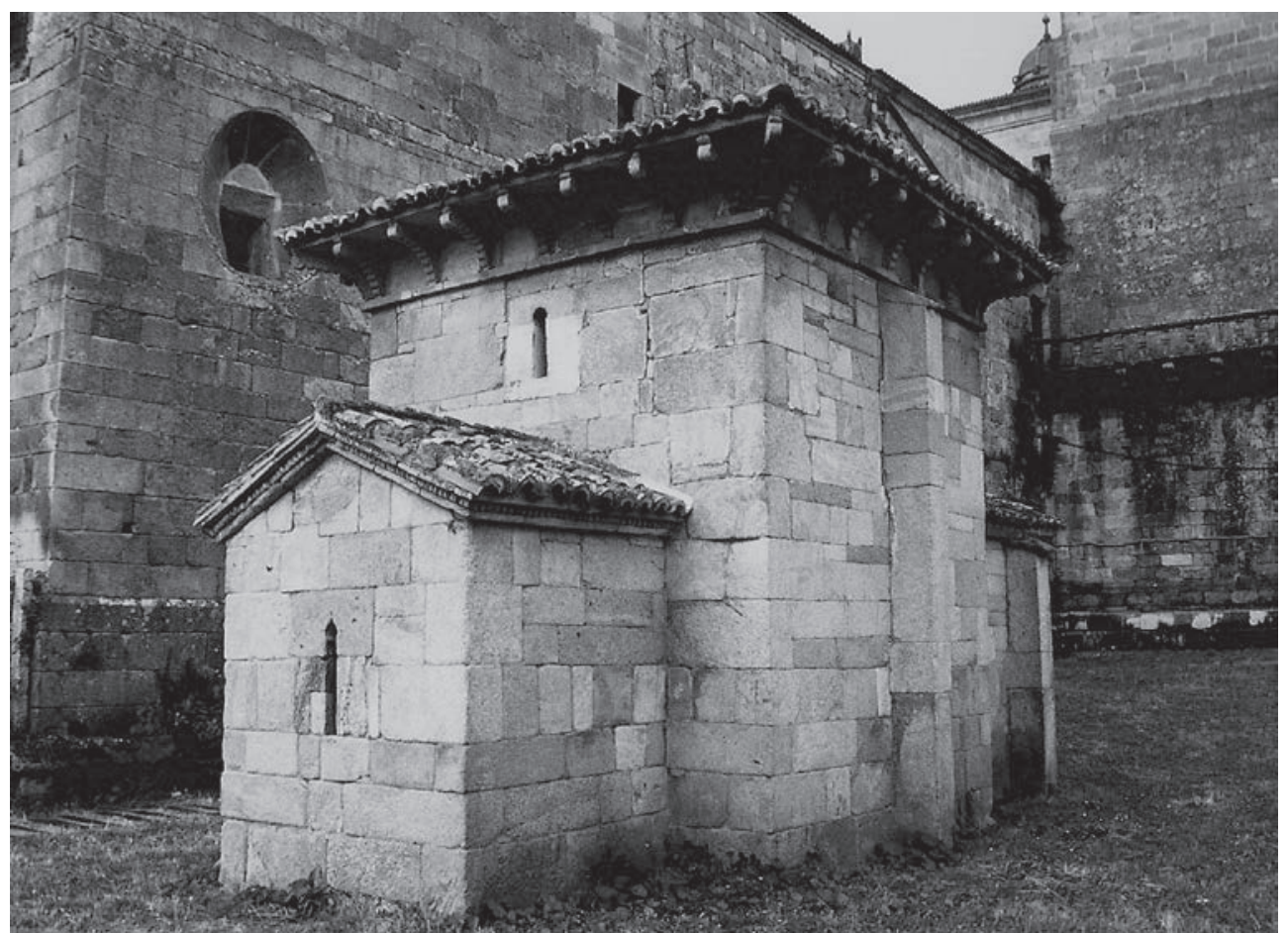

Fig. 15 El pequeño Oratorium de San Miguel, en el monasterio de San Salvador de Celanova (prov. de Ouense, c. 940), construido por San Rosendo, en honor de su hermano Froila, contando con mano de obra islámica"(@) Ángela Crespo Espinel).

dedicado a San Miguel93 (fig. 15). Según el testimonio de Ordoño, un monje celanovense que escribe a finales del s. XII, san Rosendo y su madre, Ilduara, edificaron varias ecclesiae cerca de otro edificio ya existente, el oráculo dedicado a san Martín (sacti Martini oraculum): la primera y más importante dedicada al Salvador (por su advocación, probablemente la iglesia comunitaria), la segunda a san Pedroy una tercera en honor del apóstol san Juan (¿acaso la iglesia bautismal?). Pero no olvidemos que no lejos de estas iglesias construyó, dentro del espacio monástico, un oraculum dedicado al arcángel san Miguel94. Y casos similares los encontramos en San Salvador de Samos, donde se conserva la capilla de San Julián ${ }^{95}$; en San Pedro de Montes, pues se conoce la existencia de una ermita dedicada a San Martín en tiempos del abad Vicente I (a. 923), situada a 20 pasos escasos de la actual y demolida en 1592 por orden del abad Martín del Castillo ${ }^{96}$ y en el monasterio de Montserrat, ya en la Marca Hispánica, dónde en el s. IX se localizaban al menos cuatro: la iglesia propiamente monástica, dedicada a Santa María, y las de San Acisclo, San Martín y San Pedro, todas ellas cercanas entre síp ${ }^{97}$.

\subsubsection{ESPACIOS SIN UNA DENOMINA- CIÓN ESPECÍFICA EN LOS TEXTOS}

p) Y para finalizar hablemos del espacio funerario o ad tumulandum, del cementerio monástico. Será en el último capítulo de la regla de san Isidoro (cap. XXV) dónde encontramos una escueta y única noticia relativa al espacio funerario, al territorio de los muertos, en el contexto cenobítico; y esta informa la conveniencia de que los cuerpos de los monjes fueran sepultados todos en un mismo lugar con el fin de que los que estuvieron unidos en vida siguieran estando unidos después de la muerte ${ }^{98}$. ¿Qué sabemos de los necrópolis monásticas en los reinos cristianos? Al menos hasta ahora, prácticamente nada más que su existencia.

\subsection{El monasterio dhimmí o 'monasterio del pacto' en terri- torio islámico: organización y dependencias}

Como ya dejamos dicho en 2003, de la legislación monástica aplicada en los cenobios ubicados en territorios cristianos dominados por el Islam sabemos muy poco99. Lo más probable es que se rigieran por lo estipulado en un Codex Regularum o sistema de regula mixta - con lo que esto implica -, pues se ha conservado un texto en el que se entremezclan preguntas y respuestas, de clara orientación monástica aunque de autor desconocido (Liber secundum de uitis patrum originem irae), en el códice 80 de la Real Academia de la Historia. Dicho códice fue manejado por Paulo Albaro de Córdoba y copiado en la década de los años 30-40 de la novena centuria ${ }^{100}$. Paulo Albaro, inseparable compañero del mártir Eulogio, afirmó de este último que llegó a componer reglas (regulas fratrum conponere) ${ }^{101}$, pero por el momento nada sabemos de la producción literaria de este gran elucubrator, ni siquiera con seguridad que llegara a

\footnotetext{
${ }_{93}$ M. NÚÑEZ RODRÍGUEZ, San Rosendo y una arquitectura con mentalidad fronteriza, in Arquitectura a Catalunya (segles IX, X i priera meitat de l'XI), Gerona, 1994, p. 37-64; R. VÁZQUEZ ROZAS, Geometría y proporción en el oratorio mozárabe de San Miguel de Celanova, in Norba-Arte, 26, 2006, p. 5-17; M.D. BARRAL RIVADULLA, Diálogos artísticos en el siglo X. La imagen arquitectónica de San Miguel de Celanova, in Cuaderno de Estudios Gallegos, LV, 22, 2009, p. 93-111; M. GUARDIA PONS, El oratorio de San Miguel de Celanova: arquitectura y liturgia, in Rudesindus. El legado del santo, Iglesia del Monasterio de San Salvador de Celanova (1 de octubre-2 de diciembre, 2007), Logroño, 2007, p. 130-143.

${ }_{94}^{4}$ ORDOÑO DE CELANOVA, Libro de la Vida y Milagros del obispo san Rosendo, Edición, traducción y estudio por M.C. Díaz y Díaz, Mạ. V. Pardo Gómez y D. Vilariño, con un apéndice anatomo-antropológico por J. Carro Otero, La Coruña, 1990.

${ }_{95}$ C. CASAL CHICO, El siglo X en Samos: la capilla del Salvador, un programa ideológico singular, in Rudesindus, op. cit. (n. 93), p. 248-263.

${ }^{96}$ Fr. J. HERREZUELO, op. cit. (n. 50), f. 124-129 y 281. Se trataba de una edificación "pequeña, que esta... ahora dentro de la Huerta del Convento; de esta dicen que es la mas antigua de todas": Fr. ANTONIO DE YEPES, Crónica General de la Orden de San Benito, 7 vols., Madrid, 1609-1621 (ed. Fr. Justo Pérez de Urbel, Biblioteca de Autores Españoles, 123-125, Madrid, 1959-1960), T. II, p. 202.

${ }_{97}$ M.A MUNDÓ I MARCET, Il monachesimo nella Penisola Iberica fino al sec. VII. Questioni ideologiche e letterarie, in Il Monachesimo nell 'Alto Medioevo e la formazione della civiltà occidentale, IV Settimana di studio del centro italiano di studi sull'alto medioevo, Spoleto, 1957, p. 73-118.

${ }_{98}^{8}$ San Leandro, San Fructuoso, op. cit. (n. 21), p. 125: Corpora fratrum in unum uno sepilenda sunt loco, ut quos uiuentes karitas tenuit unitos morientes locus unus implectatur.

${ }_{99}$ A.M. MARTÍNEZ TEJERA, op. cit. (n. 12), p. 59 y ss.

${ }^{100}$ M.C. DÍAZ Y DÍAZ, Manuscritos visigóticos del sur de la península. Ensayo de distribución, Sevilla, 1995, p. 51, n. 132.

${ }^{101}$ J. GIL FERNÁNDEZ, Corpus Scriptorum Muzarabicorum, T. I, Madrid, 1973, p. 332.
} 


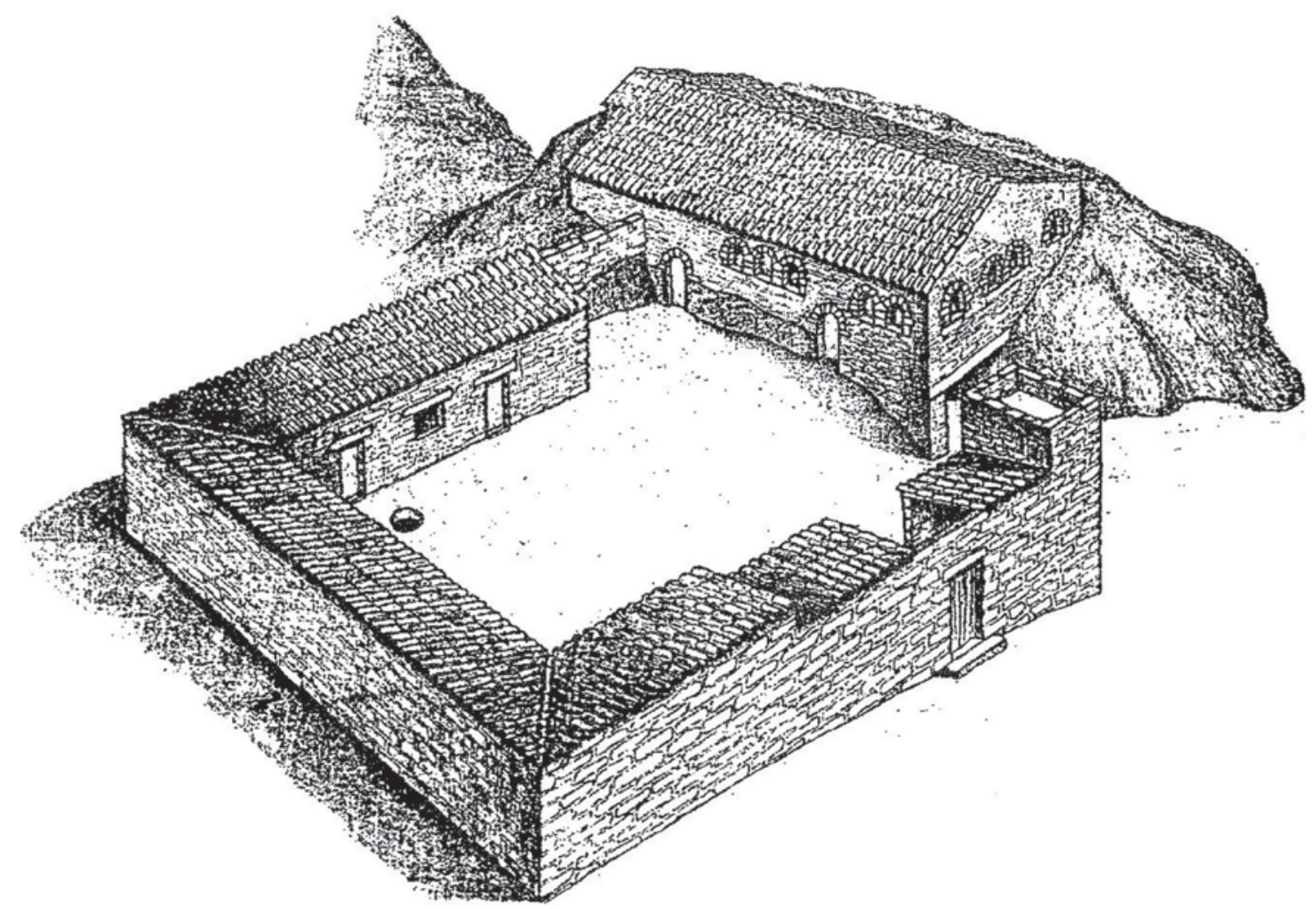

Fig. 16 Complejo monástico de Las Mesas de Villaverde (Bobastro (Málaga), construido entre los años 899-904, fue destruido pocos años después, en el 928 : reconstrucción hipotética según $R$. PUERTAS TRICAS, 2006, que refleja la existencia de una única puerta para acceder al monasterio, un recinto cerrado (conclusus) formado por la iglesia y unas pocas dependencias adosadas a su fachada norte a modo de atrio. En si mismas, las dependencias que conforman el conjunto ejercen ya de fortaleza'.

profesar la vida monástica, pero hace ya mucho tiempo que Antonio Linage encontró huellas de la influencia literaria y doctrinal benedictina en sus obras ${ }^{102}$. Los cenobios dimmíes se rigieron por un Codex Regularum en el que presumiblemente las reglas de san Isidoro de Sevilla y san Fructuoso de Braga, además de la Communis y, por supuesto, la benedictina, adquirieron un gran protagonismo: la de Isidoro por encontrarse los cenobios cordobeses en la Baetica, ámbito geográfico de aplicación originario de su regla; la de san Fructuoso como consecuencia, sin duda, de las andanzas y fundaciones efectuadas por el santo godo en estas latitudes y la Communis por testimonios como los de Tábanos.

En cuanto a la presencia del término en los textos procedentes de territorios sometidos hay que destacar la ausencia del término villa a la hora de señalar la localización de los centros monásticos o cenobíticos, predominando expresiones como vicus y viculus. ¿Quiere esto decir que desaparecieron las grandes propiedades o haciendas privadas?; evidentemente no, puesto que a partir de diversos textos de san Eulogio podemos corroborar la existencia de monasterios dúplices erigidos en haciendas privadas, en los vicus. Uno fue el de Tábanos, ubicado en el viculus del mismo nombre y famoso por el ejercicio de la vida monástica que allí llevaban uirorum atque ancillarum Dei, los primeros bajo la dirección espiritual del abad Martín y las segundas de
Isabel o Elisabeth, esta última esposa del fundador, Jeremías, y hermana de Martín. Y otro el de San Salvador, en el locus de Peña Mellaria, en el que la virgen y mártir Pomposa vivió junto con sus parientes ${ }^{103}$.

Evidentemente casos como los anteriores son lo suficientemente significativos como para poder hablar de la existencia, también en territorio sometidos, de monasterios dúplices de fundación privada, de los llamados "monasterios de patronato", erigidos en propiedades particulares. Pero se trata de monasterios familiares muy distintos a los de época goda ${ }^{104}$, ya que estos no se originaron a partir de "iglesias propias" erigidas en los dominios del fundador pues ya Simonet recordó como la legislación musulmana impedía a los cristianos disponer, ya fuera en casa alquilada o propia, de capillas u oratorios donde practicar su culto ${ }^{105}$. Otra cosa muy distinta es que, de hecho, existieran. La subsistencia de este tipo de cenobios en la novena centuria en los territorios dominados por el islam vino propiciada por el abandono de las obligaciones episcopales y marcado por las circunstancias sociales del momento: el régimen de vida cenobítico fue visto, y así se indicó hace ya más de veinte años, como "una alternativa ante los problemas sociales y religiosos de unos sectores de la población mozárabe, que buscaban un espacio donde preservar en cierto modo su unidad. De ahí que las decisiones de abrazar ese género de

${ }_{102}$ A. LINAGE CONDE, La mozarabía y Europa: en torno a San Eulogio y la regla de San Benito, in I Congreso Internacional de Estudios Mozárabes, Toledo, 1979, p. 17-27, especialmente p. 20-21.

${ }^{103}$ J. GIL FERNÁNDEZ, op. cit. (n. 101), T. II, p. 453.

${ }^{104}$ F. ARCE SÁINZ, Los monasterios cordobeses de Tábanos y Peñamelaria a lo luz de los textos y su entorno histórico, in Boletín de Arqueología Medieval, 6, Madrid, 1992, p. 157-170, especialmente p. 161.

${ }^{105}$ F.J. SIMONET, Historia de los Mozárabes de España, deducida de los mejores y más antiguos testimonios de los escritores cristianos y árabes, Memorias de la Real Academia de la Historia, XIII, Madrid 1897-1903 (reed. Madrid, 1985), T. I, p. 84. 
vida frecuentemente fuesen tomadas en el plano familiar" ${ }^{106}$.

¿Cómo se organizaban los 'monasterios dimmíes' o ‘monasterios del pacto'? ¿Estuvieron estos cenobios acotados mediante algún tipo de fortificación permanente? Lo único que sabemos hasta el momento es que estuvieron aislados de su entorno, pues en el $\mathrm{Me}$ moriale Sanctorum se dice del de San Salvador de Peñamelaria que una única puerta permitía acceder a su interior: arresta clave portam monasterio inconsuetus aperit minimoque tantum modo claue superposito retrusit (vid., nota n. 103) Para otros casos, como el de los monasterios localizados en Bobastro (prov. de Málaga), desconocemos por el momento si se dotaron de ella, aunque alguna reconstrucción hipotética apunta a que carecieron de cerca ${ }^{107}$ (fig. 16).

a) De las dependencias $u$ edificios

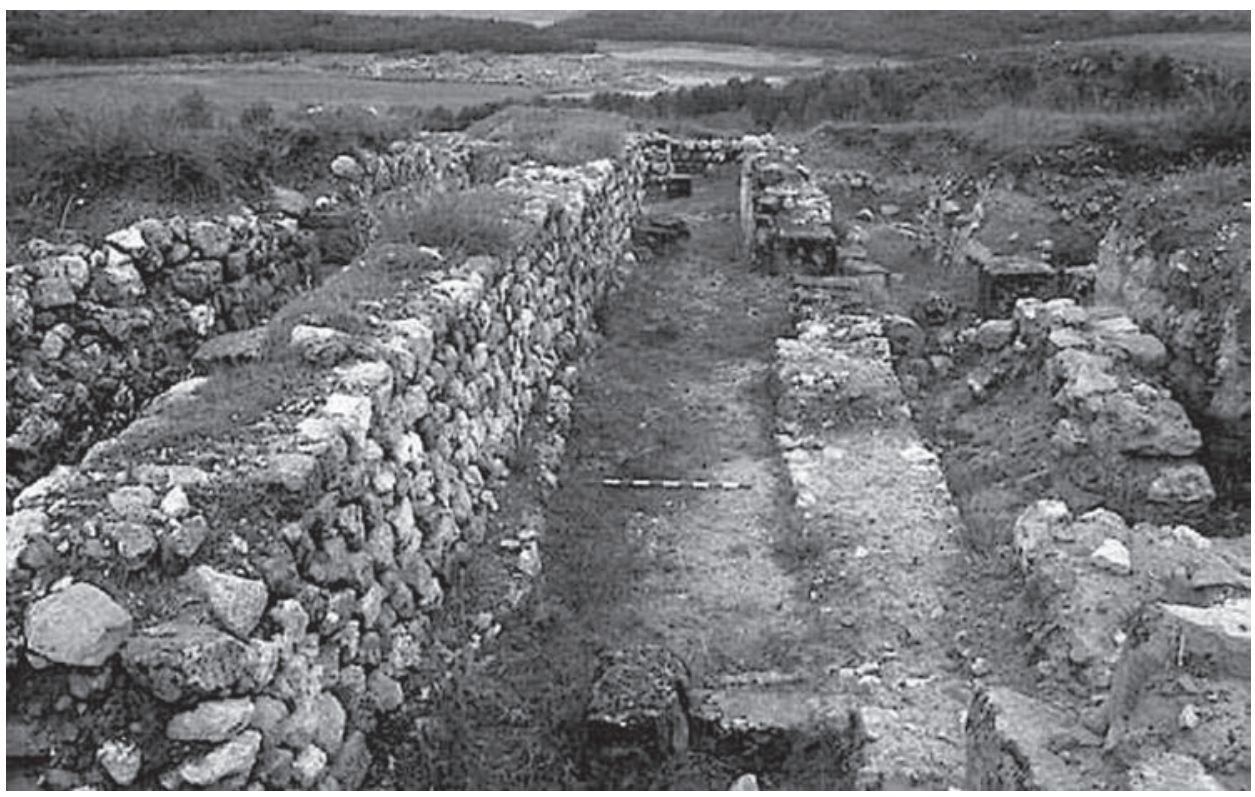

Fig. 17 Cilla del monasterium Servitanum (Arcavica, Cuenca): este edificio, construido en los ss. VI-VII, fue compartimentado longitudinalmente en dos espacios a lo largo del s. IX que conformaban el espacio monástico (C) BARROSO CABRERA et alii, 2008).

es muy poco lo que sabemos. Entre las destinadas a la producción, elaboración, transformación y almacenaje cabría destacar varias: la relacionada con la producción libraria, con la elaboración y copia de códices, tarea que se llevaría a cabo en el scriptorium o scrinum, que así lo denomina San Eulogio $^{108}$; códices que se custodiaban en un espacio designado por los dimmíes (en los epigramas del arcipreste cordobés Cipriano) con los términos teca y librorum ${ }^{109}$.

Otra dependencia fue el cellarium o almacén, como muestran los restos arqueológicos exhumados en el monasterium de Arcavica, en la prov. de Cuenca, excavados y estudiados por Barroso y Morín hace ya más de 20 años ${ }^{110}$ (fig. 17). En este último caso - recordemos, un monasterio de fundación tardoantigua que en la alta Edad Media permanecerá en territorio bajo control del califato de Córdoba hasta el año 1031 - puede que nos encontramos, y así lo indicamos hace ya años, ante un horreum o granaria que en el s. IX se transformó en almacén, en este caso de productos recolectados no transformados y de líquidos ${ }^{111}$. De hecho los materiales cerámicos encontrados ofrecen muy distintos usos y cronologías.

Y destacar, por último, la existencia de presas destinadas a riegos y conducciones para uso agrícola, incluso de espacios cultivables intramuros, en el recinto de monasterios como los de Santa María de Melque o en Santa Lucia de El Trampal (prov. de Cáceres) en la alta Edad Media' ${ }^{12}$ (fig. 18).

b) Entre los edificios y estancias monásticas de cara al exterior cabe destacar, como ya se ha hecho, la presencia de un espacio dedicado a la asistencia puesto que en su Memoriale Sanctorum, San Eulogio hace alusión a la posibilidad de hospitium, de alojamiento, en los monasterios de Tábanos y Cuteclara ${ }^{13}$. Y muy probablemente existiera alguna infraestructura edilicia de este tipo en el Armilatense o de San Zoilo, ya que Armillat (Armilla) era un punto de referencia importante en la red viaria que unía Córdoba y Toledo $^{114}$. ¿Contaron los cenobios dimmíes con hospedería monástica? Teniendo en cuenta, como ya se ha dicho, que la legislación musulmana obligaba a los cristianos a dar hospedaje gratuito a los peregrinos musulmanes durante 3 días en sus iglesias y monasterios, así debió ser, al menos en los de nueva fundación ${ }^{115}$. Y si hasta esos momentos el cenobio, mediante la atención social, fue una referencia asistencial a menudo única e insustituible, no hay motivos - al menos aparentes - para pensar que el monasterio dimmí dejase de ejercer tal actividad. Me gustaría señalar que muy probablemente el edificio porticado del ala norte del recinto

\footnotetext{
${ }^{106}$ A. YELO TEMPLADO, El monacato mozárabe. Aproximación al oriente de Al-Andalus, in La cueva de la Camareta, Agramón, Hellín-Albacete, Antigüedad y Cristianismo, X, Murcia, 1993, p. 453-466, especialmente p. 460.

${ }_{107}$ V. MARTÍNEZ ENAMORADO, Algunas consideraciones espaciales y toponímicas sobre Bobastro, in Al Quantara, XVII, 1996, p. 59-77; ID., La basílica mozárabe hallada en la ciudad de Bobastro (Ardales, Málaga). Intervención arqueológica en el cerro de la Tintilla-Mesas de Villaverde. Julio-Agosto de 20o1, in Anuario Arqueológico de Andalucía, Consejería de Cultura, Dirección de Bienes Culturales, II, 2001, p. 683-691; ID., Sobre las cuidadas iglesias de Ibn Hafsun. Estudio de la basílica hallada en la ciudad de Bobastro (Ardales, Mälaga), in Madrider Mitteilungen, 45, Madrid, 2004, p. 507-531.

${ }^{108}$ J. GIL FERNÁNDEZ, op. cit. (n. 101), T. II, p. 293.

${ }^{109}$ Lírica mozárabe, introducción, comentarios, texto latino y traducción de Gonzalo del Cerro Calderón y J. Palacios Royán, Málaga, 1998, p. 86-87.

${ }^{\text {no }}$ R. BARROSO CABRERA - J. MORÍN DE PABLOS, La ciudad de Arcávica y la fundación del monasterio Servitano, in Hispania Sacra, XLVIII, 97 ,1996, p. 149-187.

${ }^{m}$ A. M MARTÍNEZ TEJERA, op. cit. (n. 1), p. 26.

${ }^{112}$ Edificios surgidos, en opinión de los 'mozarabistas', en la segunda mitad del s. VIII-primera mitad del s. IX: L. CABALLERO ZOREDA - Mạ. A UTRERO AGUDO, El ciclo constructivo de la Alta Edad Media hispánica. Siglos VIII-X, in Archeologia dell'Architettura, XVIII, 2013, p. 127-146. Nuestra postura al respecto, alejada también de la de los 'visigotistas', en A.M. MARTÍNEZ TEJERA, Estudios sobre las 'iglesias arabizadas' del siglo X en el reino de León, Berlín, 2016. ${ }^{13}$ F.J. ARCE SÁINZ, op. cit. (n. 105).

${ }^{114}$ A.M. MARTÍNEZ TEJERA, op. cit. (n. 3), T. I, p. 336 y n. 1558.

${ }^{15}$ M. NIETO CUMPLIDO, Estatuto legal de los mozárabes cordobeses, in I Congreso Nacional de Cultura Mozárabe, Córdoba, 1996, p. 27-36, especialmentep. 35.
} 


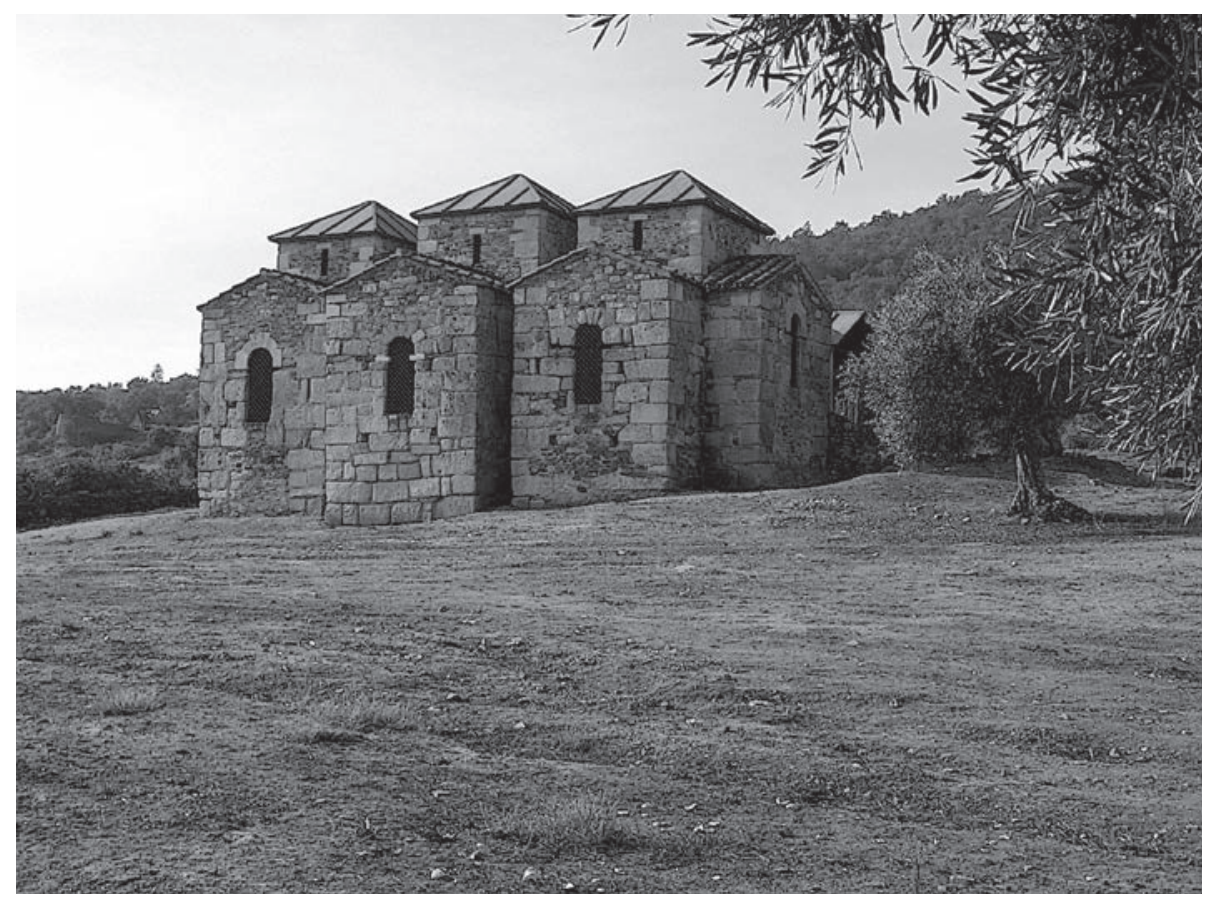

Fig. 18 La iglesia de Santa Lucía de El Trampal (Cáceres), vista desde el noreste: tanto este monasterio como el de Melque muestran una compleja red hidráulica con presas en las tierras de alrededor; pero también en su interior, lo que indica la existencia de espacios cultivables en el interior del recinto monástico (C) Artemio M. Martínez Tejera). bles, es de suponer que existieran, como los espacios destinados a la alimentación, vivienda y a la oración. Entre los primeros cabría señalar, la presencia de un espacio para la alimentación, de un refectorium, en el monasterio de Santa María de Melque, concretamente en el ala oriental del recinto principal: un edificio de tres naves, la central de mayor anchura, y probablemente con un piso superior, aunque no sabemos si también destinado a la misma función ${ }^{116}$ (fig. 19B).

d) Los textos tardoantiguos hablan de las 'celdas de los monjes' (cellae y cellulae), incluso de un tipo de celda para la reclusión, con carácter penitencial o de castigo ${ }^{117}$. ¿Existieron celdas individuales en los cenobios localizados en territorios sometidos y erigidos ex novo? Parece ser que si, puesto que la virgen Columba, en su deseo de profundizar en su vida interior, solicitó la concesión o adjudicación de una celda separada y ubicada en un ángulo del monasterio (ipsa claustra in quodam angullo cellula sibi daretur) dúplice de Tábanos para su uso exclusivo e individual, petición para la que
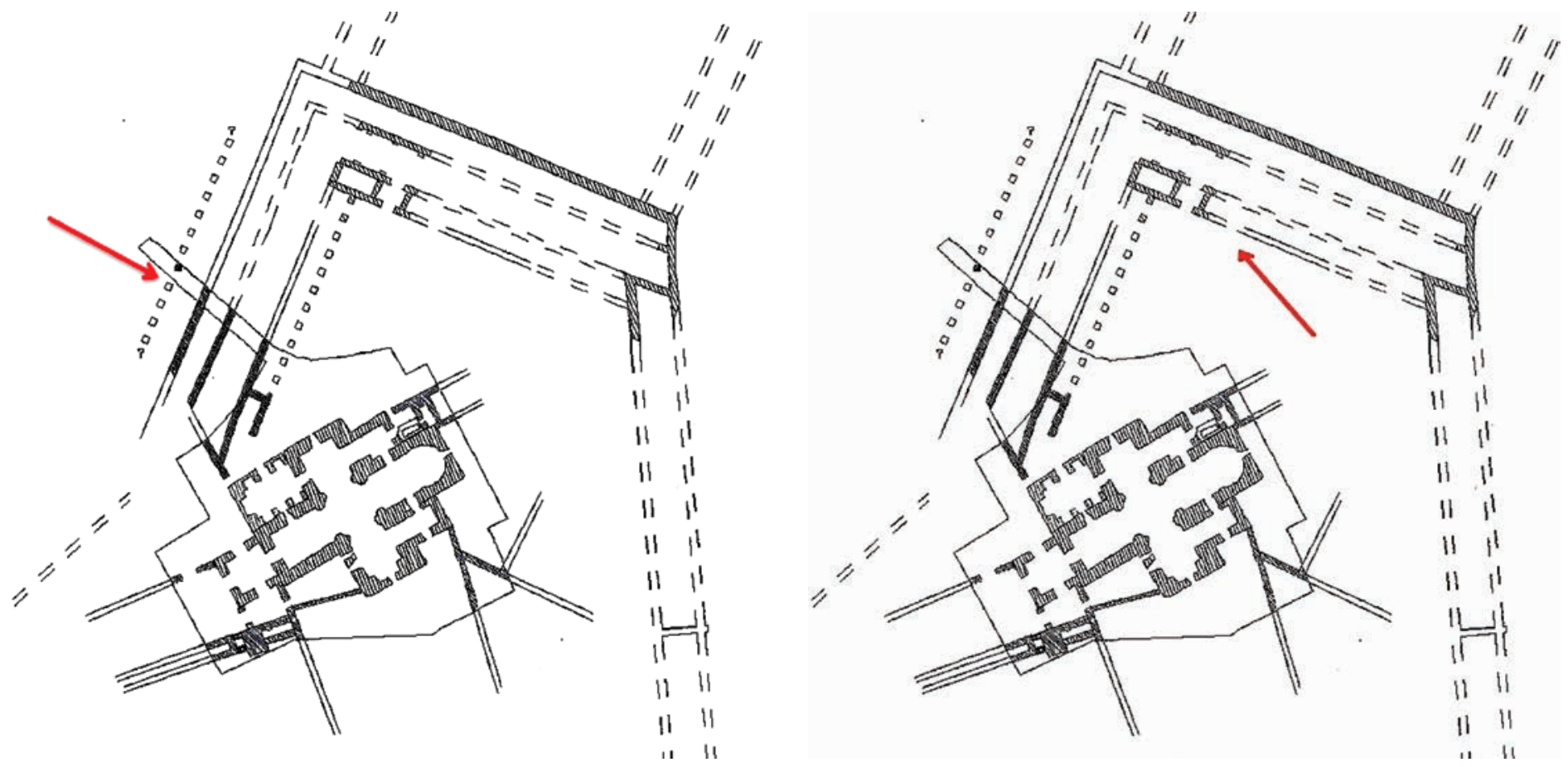

Fig. 19 Planta de Monasterio de Santa María de Melque (Toledo), E. 1/1.000, según L. CABALLERO ZOREDA, 2006, e indicación del espacio que se ha identificado con ámbitos habitacionales y asistenciales: cellae, hospedería (A) y refectorium (B).

central de Santa María de Melque pudo haber ejercido dicha función (fig. 19A), y más localizándose el monasterio en un cruce de caminos.

c) Más abundantes son las noticias que conservamos respecto a los edificios y estancias para uso de los cenobitas, aunque guardan silencio de algunas que, por indispensa- obtuvo licencia, llevando entonces una vida solitaria dentro del propio cenobio ${ }^{118}$.

Por lo que sabemos hasta el momento, las celdas monásticas hispanas altomedievales pudieron ser de uso individual aunque espacialmente formasen parte de una estructura o edificio más amplio: esto es lo que al parecer ocurre con el

\footnotetext{
${ }^{116}$ L. CABALLERO ZOREDA, El conjunto monástico de Santa María de Melque (Toledo). Siglos VII-IX (Criterios seguidos para identificar monasterios hispánicos tardo antiguos), in Monjes y monasterios hispanos en la Alta Edad Media, Logroño, 2006, p. 99-146, especialmente p. 125 y ss.

${ }^{17}$ A.M. MARTÍNEZ TEJERA, op. cit. (n. 1), p. 30.

${ }^{118}$ ID., op. cit. (n. 12), p. 62-63; L. CABALLERO ZOREDA, op. cit. (n. 117), p. 125 y ss.
} 


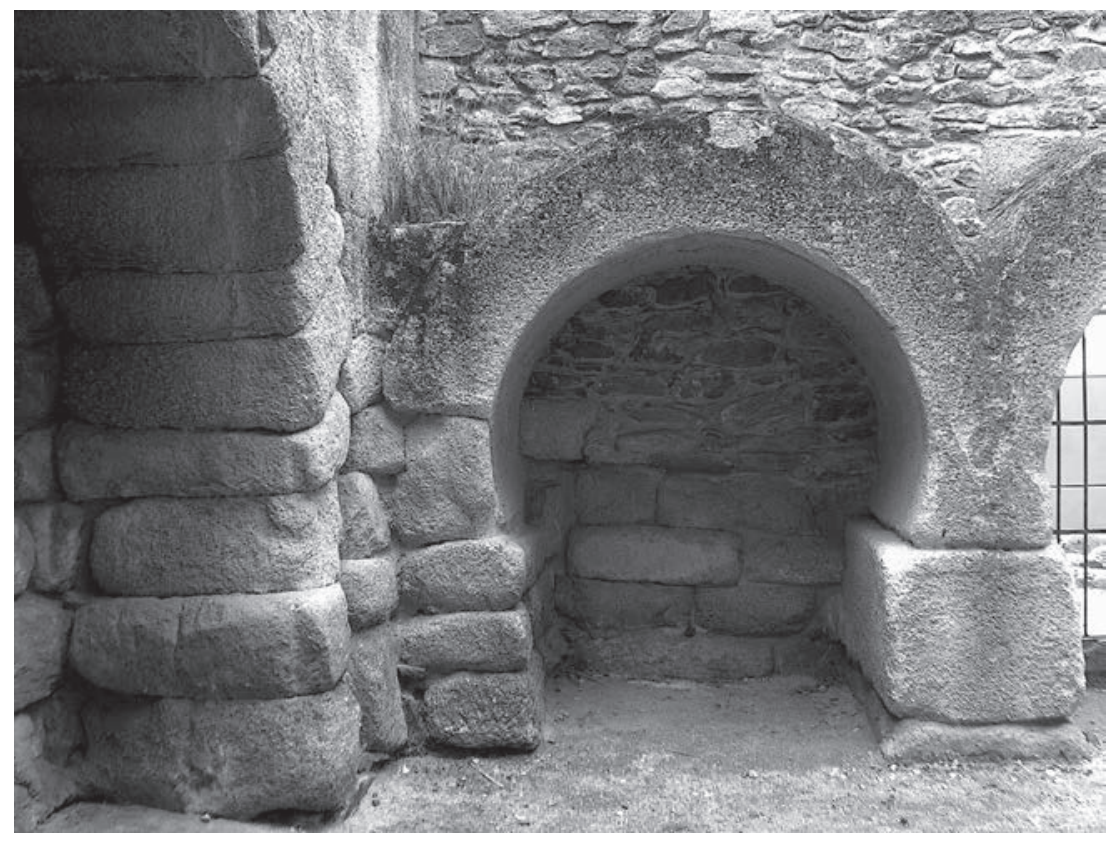

Fig. 20 Santa María de Melque (Toledo), detalle del muro occidental de la 'habitación trasera', adosada al muro norte del edificio cultual y a la que, muy probablemente, solo se tendría acceso desde la iglesia. Resulta evidente que este espacio no ejerce de espacio organizativo y distribuidor, que es la función esencial del claustro. Muy probablemente se trate de la monumentaización de un espacio funerario preexistente, el del cementerio de los monjes (C) Ángela Crespo Espinel).

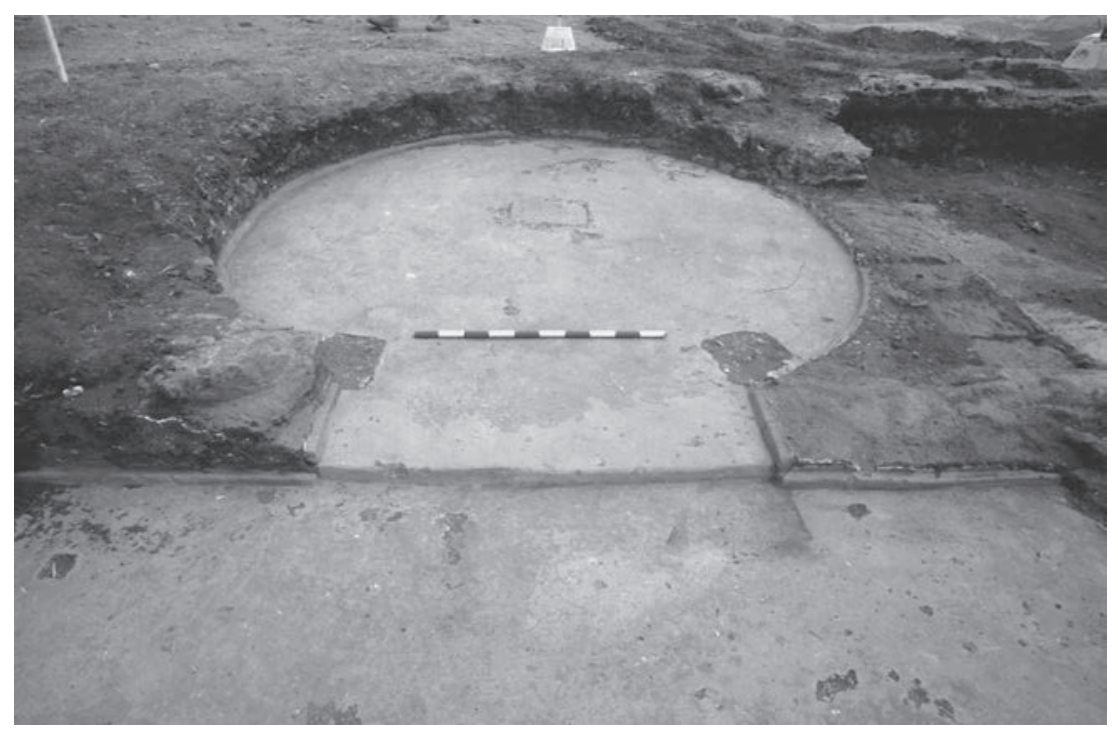

Fig. 21 Ábside principal, con una herradura en planta muy acusada, de la iglesia descubierta en Bobastro (Málaga) durante la campaña arqueológica llevada a cabo en 2001 (C) Virgilio Martinez Enamorado). ala norte del recinto principal de Santa María de Melque, donde se han localizado varios espacios que se han interpretado de uso habitacional ${ }^{119}$ (vid., fig. 19A).

e) ¿Un espacio claustral en el monasterio o un espacio monástico cerrado (claustrum)? Si en un primer momento se consideró la "habitación trasera" de Santa María de Melque como un primer esbozo de un 'claustro monástico', al poco tiempo prevaleció la opinión de que nos encontrábamos ante un espacio funerario ${ }^{120}$ (fig. 20). Pero que neguemos su identificación con un espacio distribuidor, no significa que visualmente, incluso por su localización, no nos lo 'recuerde'.

Al narrar las vicisitudes de la futura mártir Columba, san Eulogio describió muy de pasada la distribución de las comunidades masculinas y femeninas del monasterio dúplice de Tábanos, en el que los claustros de las vírgenes (claustra feminarum) se encontraban separados - por altas paredes - de las celdas de los monjes: claustra feminarum a cellulis monachorum altis interiectis disparata maceriis ${ }^{121}$. ¿Podemos hablar de claustra virorum frente a claustra feminarum, entendiendo claustra como un espacio arquitectónico determinado?

Y otro documento de la época, la passio de la virgen Argentea (redactada poco después del a. 931), hija (o puede que nieta, según Virgilio Martínez Enamorado) ${ }^{122}$ del rebelde 'Umar ibn Ḥafșūn, relata como esta rogó a su padre que construyera - con el fin de aislarla del torbellino del siglo - un alojamiento cerrado, para ella y sus compañeras, debajo del palacio: reclusum michi hospitium infla huius palatii claustra construi, quo recedens a saeculi turbinibus liberius possem, puellis michi comitantibus, uotum perpetrare ${ }^{123}$ : ¿no se tratará de uno de los monasterios conocidos hasta el momento en Bobastro? (fig. 21).

f) Un ámbito para el descanso, que en los textos altomedievales aparecen bajo las denominaciones de dormientium locum y durmiturium. De él podemos afirmar que era el espacio en el que se encontraban las camas o lechos, que San Eulogio denomina cubile, torus, stramentum y stratum, y que eran dos en los monasterios dúplices pues nuevamente san Eulogio, en su capítulo dedicado a la virgen y mártir Pomposa, nos presenta a Félix,

\footnotetext{
${ }^{19}$ Otra cosa bien distinta son las celdas para reclusos (reclusi), abundantes en las fuentes tardoantiguas, pero no en las altomedievales. Investigadores pioneros como Manuel Gómez-Moreno o Helmut Schlunk consideraron celdas monásticas las habitaciones o habitáculos existentes en edificios de los ss. VII-X, como Santa Comba de Bande (Ourense), San Pedro de la Nave (Zamora) o Santa María de Quintanilla de las Viñas (Burgos) y las naves laterales de Sao Giâo (Nazaré, Portugal), San Pedro de la Mata (Toledo) y Recopolis (Guadalajara): M. GÓMEZ-MORENO Y MARTíNEZ, Exploraciones en Santa Comba de Bande, in Boletín de la Comisión de Monumentos de Orense, XIV, 1993-1994, p. 47-51, especialmente p. 50; H. SCHLUNK, La iglesia de S. Giâo, cerca de Nazaré. Contribución al estudio de la influencia de la liturgia en la arquitectura de las iglesias prerrománicas en la Península Ibérica, in Actas del II Congreso Nacional de Arqueología, Coimbra, 1971, p. 509-529, especialmente p. 513. Respecto a Bande, entendemos que el hecho de que las habitaciones respondan a un segundo momento constructivo, también altomedieval, no invalida la hipótesis funcional de Gómez-Moreno, como se ha dicho: F.J. MORENO MARTÍN, op. cit. (n. 1), p. 203 y nota no 12.

${ }^{120}$ A.M. MARTÍNEZ TEJERA, op. cit. (n. 40), p. 146-148 y n. 47; ID., De nuevo sobre áreas ceremoniales y espacios arquitectónicos intermedios en los edificios hispanos (ss. IV-X): atrio y pórtico, in Boletín de Arqueología Medieval, 7, Madrid, 1993, p. 163-215, especialmente, p. 173 y ss.

${ }^{121}$ ID., op. cit. (n. 12), p. 63.

${ }^{122}$ V. MARTÍNEZ ENAMORADO, 'Umar ibn.Haf.sūn. De la rebeldía a la construcción de la dawla. Estudios en torno al rebelde de al-Andalus (880-928), Cuadernos de la cátedra “Ibn Khaldun” de Estudios de Medio Oriente y África del Norte no 5, San José de Costa Rica, 2012.

${ }^{123}$ A.M. MARTÍNEZ TEJERA, op. cit. (n. 12), p. 63.
} 
abad peñamelariense, y a unos hermanos suyos regredientibus ad cubile $e^{124}$.

g) Una estancia o dependencia para el cuidado de ancianos y enfermos, la enfermería, que aparece en los textos como locus aegrotantium y domus infirmorum, y de la que conocemos su existencia gracias a un texto en el que se cuenta como 'Abd al-Raḥmān al-Nāṣir III, aquejado de una fuerte dolencia de oído, acudió a un cenobio de la sierra cordobesa para ser atendido por un monje, obteniendo unos resultados favorables ${ }^{125}$.

h) Un ámbito para la reunión y la reflexión en comunidad, a modo de 'sala capitular', en el que se inculcaba al cenobita lo conocido, de ahí que a las mismas Paulo Albaro de Córdoba las denomine, a mediados del s. IX, conlatio o confesio, es decir, colación o confesión; estas reuniones tenían lugar, al parecer, después de la puesta de sol (signum dandi in diurnis officiis, siue in conlatione uel in collecta pos solis occubitum), correspondiendo "al de semana", dar la señal para la conferencia ${ }^{126}$.

i) Un espacio para el aprendizaje, como la escuela, no faltó en los 'cenobios del pacto' y con ella contaron los monasterios de San Zoilo o Armilatense en la segunda mitad del s. IX, Tábanos, Santa María de Cuteclara, San Cipriano, San Félix de Froniano, San Salvador de Peñamelaria y San Acisclo. En esta última escuela recibieron educación los mártires Perfecto, Sisenandoy Anastasio. En ellas los futuros

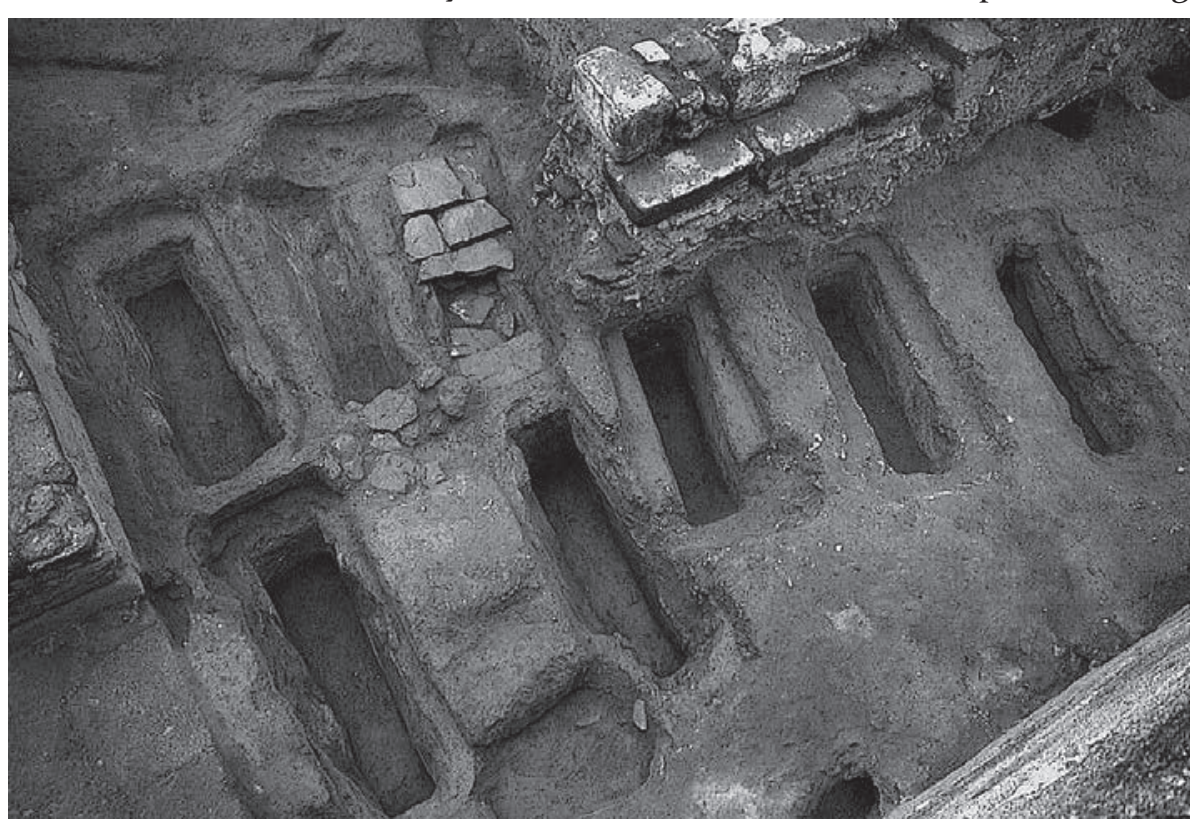

Fig. 22 Santa María de Melque: imágene aérea del cementerio localizado entre el porche (a la izqd.) y la llamada 'habitación trasera' (C Caballero Zoreda, 2007). cenobitas recibían la instrucción básica (aprendizaje del latín, técnicas literarias, estudio del ars gramatica, etc.,) de mano de los magistri litterarum ${ }^{127}$.

j) Un espacio para la oración. Se llegó a afirmar hace años, a partir del argumentum ex silentium de los textos de San Eulogio, que los monasterios dimmís y dúplices de Tábanos y Peñamelaria carecieron de iglesia, de un espacio para la oración en común; que fueron simples casas de retiro devocional en las que se celebraría una especie de misa individual en la intimidad de la celda, es decir, algo similar a los ribāt-s y rābita-s musulmanas, en donde los residentes habitaban celdas-oratorios con nichos-mihrab para la oración individual ${ }^{128}$. Sin embargo, los textos del propio Eulogio recogen varias actividades que, sin duda, se desarrollaban en un espacio sagrado, como la salvaguarda de las reliquias de los mártires o la celebración de determinadas fiestas litúrgicas ${ }^{129}$. Es más, ya Puertas Tricas indicó, basándose en diversos testimonios de san Eulogio, que los monasterios dúplices ubicados en los alrededores de Córdoba a mediados del s. IX compartían, como estancia común, la iglesia ${ }^{130}$, tal y como sucedía en época tardoantigua, añadimos nosotros, con las iglesias con dos coros y/o con contraábside. No obstante, no deja de resultar extraño que las mártires Columba y Pomposa, familiares directos de los nobles fundadores de estos cenobios, no recibieran enterramiento en sus correspondientes iglesias.

k) Y para concluir este breve recorrido por algunos de los espacios, estancias o dependencias con que contaron los cenobios dimmíes - los 'monasterios del pacto' - haré referencia al espacio ad tumulandum ${ }^{131}$. Un texto datado en los ss. IX-X, el epígrafe del abad Recosindus -conservado en la Escuela Nacional de Atarfe (Granada) - nos sugiere la posibilidad de que los cenobitas dimmíes se hicieran enterrar en urnas, una modalidad de enterramiento especialmente utilizada por los cenobitas del otro lado del Mediterráneo, especialmente en Siria: RECOSINDI ABBA HIC LATET URNULA, es decir, "Aquí se esconde la pequeña urna de Recosindo abad"132. Otros ejemplos los encontramos en algunas inscripciones y en epitafios literarios, como en los de Samson y Cipriano $^{133}$. Una hipótesis que podría reforzarse teniendo en cuenta que, precisamente, en los cenobios sirios los sarcófagos no estaban destinados a individualidades (excepto

\footnotetext{
${ }^{124}$ J. GIL FERNÁNDEZ, op. cit. (n. 101), T. II, p. 453.

${ }^{125}$ J.VERNET, Los médicos andaluces en el 'Libro de las generaciones de médicos'de Ibn Yulyul, in Anuario de Estudios Medievales, 5, Madrid, 1968 , p. 445-462. ${ }^{126}$ F. DELGADO LEÓN, Álvaro de Córdoba y la polémica contra el Islam. El Indiculus Luminosus, Córdoba, 1996, p. 107 y 109. P.P. HERRERA ROLDÁN, Léxico de la obra de San Eulogio, Servicio de Publicaciones de la Universidad de Córdoba. Serie monografías no 255, Córdoba, 1997, p. 109.

${ }^{127}$ Respecto a las scholae en los territorios sometidos, animadas por las collatio: D. MILLET-GÉRARD, Chrétiens mozarabes et culture islamique dans L'Espagne des VIII ${ }^{e}-I X^{e}$ siècles, Paris, 1984, p. 54-65; F. GONZÁLEZ MUÑOZ, Latinidad mozárabe. Estudios sobre el latín de Álvaro de Córdoba, La Coruña, 1996, p. 17-19.

${ }^{128}$ S. GAREN, Santa María de Melque and Church Construction under Muslim Rule, in Journal of the Society of Architectural Historians, LI, 3, 1992, pp. 288-305, especialmente p. 304 .

${ }^{129}$ F. ARCE SÁINZ, op. cit. (n. 105), p. 164.

${ }^{130}$ R. PUERTAS TRICAS, op. cit. (n. 6), p. 129.

${ }^{131}$ A.M. MARTÍNEZ TEJERA, op. cit. (n. 12), p. 65 y ss.

${ }_{132}$ S. MARINER BIGORRA, Epitafio versificado y acróstico del abad mozárabe Recosindo, in Ampurias, XXII-XXIII, 1960-1961, p. 317-322.

${ }^{133}$ J. VIVES GATELL, Inscripciones cristianas de la España Romana y Visigoda, Madrid-Barcelona, 1942 (2ª ed. ampliada, Barcelona 1969), ins. ํㅗㅇ 285, 509; J. HERRERA ROLDÁN, op. cit. (n. 128), p. 82-83 y 90-91.
} 


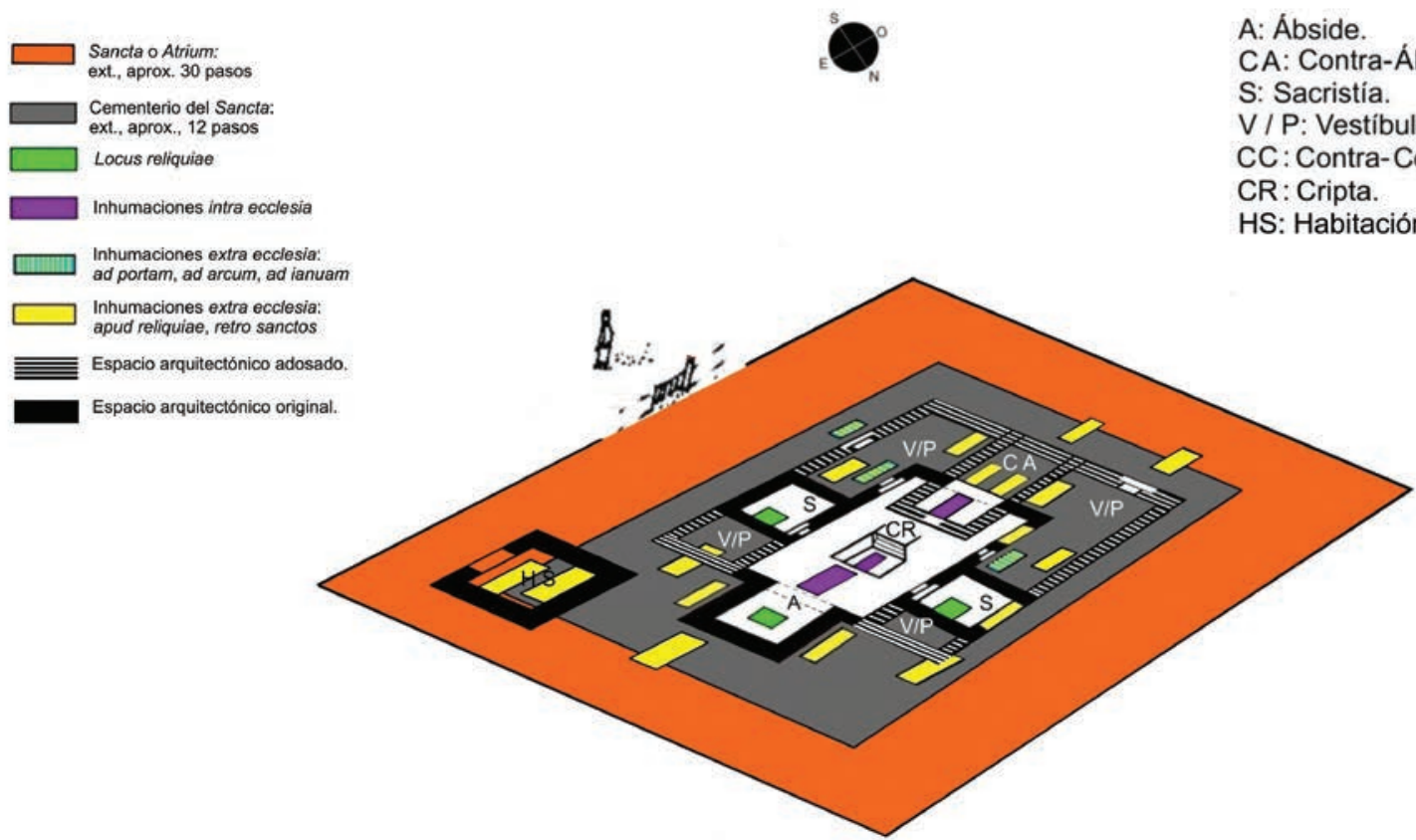

Fig. 23 El espacio eclesial hispano y su relación con el mundo de los Muertos en la Antigüedad Tardía y Alta Edad Media, según A.M. MARTÍNEZ TEJERA, 2007 (modificada 2010).

si se trataba del monje fundador o de un asceta muerto en olor de santidad) sino a 'categorías' de monjes; es decir, en un mismo sarcófago se inhumaban varios cadáveres ${ }^{134}$.

Y esos sarcófagos y urnas pudieron ser los habitantes de la 'habitación trasera' de Santa María de Melque, un espacio arquitectónico añadido que en el ámbito formal y planimétrico nosotros relacionamos con las edificaciones - en ocasiones aisladas pero en otras formado parte del espacio cultual - que, a modo de sepulcro colectivo o memorion, encontramos en determinados cenobios sirios de los ss. V-VI: Qala 'at et-Taffah, Qasr el-Garbi y de Qala 'at Sama 'an. Esta 'habitación trasera' asumió desde el momento de su construcción una función cementerial ${ }^{135}$. Pero la 'habitación trasera' no fue el único espacio funerario asociado a la iglesia de Melque, y aunque las posibilidades son muchas, en este caso otro cementerio se localiza a occidente, a los pies de la iglesia, precisamente delante de la 'habitación trasera' y junto al pórtico (fig. 22). Y es que la relación espacial entre la iglesia y los cuerpos de los difuntos puede llegar a ser muy amplia, eso si siempre en vinculación con su status ${ }^{136}$ (fig. 23).

Estos espacios cementeriales tampoco se vieron libres de saqueos y violaciones, protagonizadas a veces por las propias autoridades dimmíes; una lamentable actuación que, con respecto al conde Servando, ya fue duramente censurada por el abad Samson en su segundo libro del Apologeticus: "Y todavía, no contento con la muerte de los suyos, no pudo evitar romper el descanso de los muertos, pues los cuerpos de aquellos que fueron puestos bajo las aras de Dios los sacó de tan insigne lugar y los mostró a los fieles del rey"137.
Otra cosa fue el enterramiento de los considerados 'mártires de Córdoba' en la segunda mitad del s. IX, entre los años 850-859, en su mayoría monjes. Los escritos de Eulogio y Paulo Albaro, junto con algún que otro texto hagiográfico, nos permiten conocer el lugar en el que recibieron sepultura algunos de ellos, si bien es verdad que en la mayoría de los casos resulta imposible precisar su localización topográfica más allá de un impreciso: "cerca del mártir", "junto a”, "cerca de", "en la basílica o aula”, etc., compartiendo así una de las características que mejor definen los denominados epitafios 'ad sanctos' de entre los ss. IV-Vy finales del s. VII: su vaguedad e imprecisión a la hora no sólo de designar el nombre del edificio en la que fueron inhumados sino también el espacio arquitectónico en el que lo hicieron, quien sabe si movidos por razones de seguridad ${ }^{138}$.

Por San Eulogio sabemos que algunos de los monjes y mártires cordobeses fueron enterrados "en" espacios cenobíticos, aunque en muchos casos no se especifique el lugar exacto: en San Salvador de Peñamelaria, situado no lejos (haud procul) de la ciudad de Córdoba; en el cenobio de Cuteclara o coenobio Cuteclarensi; de los Tres Santos. Yaunque desconocemos la ubicación exacta del enterramiento del propio San Eulogio, sabemos que éste último poco después de haberse efectuado fue trasladado in basílica, por lo que hay que suponer que en un principio permaneció fuera de ella ${ }^{139}$.

Los testimonios parecen indicar que fue la basílica el lugar en el que mayoritariamente fueron enterrados los monjes dimmíes cordobeses martirizados, en las de San Acisclo, San Zoilo, de los Tres Santos ${ }^{140}$, Santa Eulalia de

${ }_{134}$ I. PEÑA, La desconcertante vida de los monjes sirios. Siglos IV-VI, Salamanca, 1985, p. 74.

${ }^{135}$ A.M. MARTÍNEZ TEJERA, op. cit. (n. 1), p. 33-34.

${ }^{136}$ ID., op. cit. (n. 121); J. LÓPEZ QUIROGA - A.M. MARTÍNEZ TEJERA, op. cit. (n. 91).

${ }^{137}$ J. GIL FERNÁNDEZ, op. cit. (n. 101), T. II, p. 551.

${ }^{138}$ A.M. MARTÍNEZ TEJERA, op. cit. (n. 12), p. 65 y ss.

${ }^{139}$ Ibidem, p. 66.

${ }^{140}$ Un edificio identificado con la actual iglesia de San Pedro de Córdoba: P. DE MADRAZO, Córdoba (Sus monumentos y artes, su naturaleza e historia), Barcelona, 1884 (reed. Barcelona, 1980), p. 442. 
Fragellas, San Ginés de Terzios y San Cristóbal. ¿En algún lugar en especial, nos podíamos preguntar? Los textos sólo indican que se efectuaron tanto en el interior de San Zoilo como en el exterior. Por lo general, las inhumaciones se efectúan en iglesias o basílicas no urbanas y preexistentes, lo que ha de ponerse en relación con la conflictiva situación que vivía la comunidad dimmiyyūn cordobesa de aquellos momentos y con las múltiples y alternantes disposiciones restrictivas en materia constructiva. ¿Cómo explicar si no que ninguno de los mártires cordobeses fueran enterrados en la basílica de San Cipriano? ¿Por qué no dice a qué distancia se encontraban de la ciudad? Una posible explicación es que fuese un edificio cultural urbano, y de hecho así lo hace saber el obispo Recemundo en su calendario del a. 961

\section{$3^{\circ}$ CONLUSIONES}

¿Cuáles son las dependencias que podríamos encontrar en los cenobios hispanos altomedievales? De acuerdo a los textos, a lo largo de los siglos altomedievales los monasterios hispanos pudieron llegar a contar con un buen número de dependencias, en ocasiones rodeadas por un muro o cerca: dieciocho en los monasterios libres y trece en los monasterios del pacto; sin embargo, a nivel arqueológico (y no sin graves y fuertes contradicciones) tan solo somos capaces de hablar de cinco estancias en los monasterios libres y de seis en los del pacto. Otros espacios, como los tres destinados a la oración y a los muertos, ya se conocían por la Historia del Arte y de la Arquitectura, o por la Epigrafía, antes que por

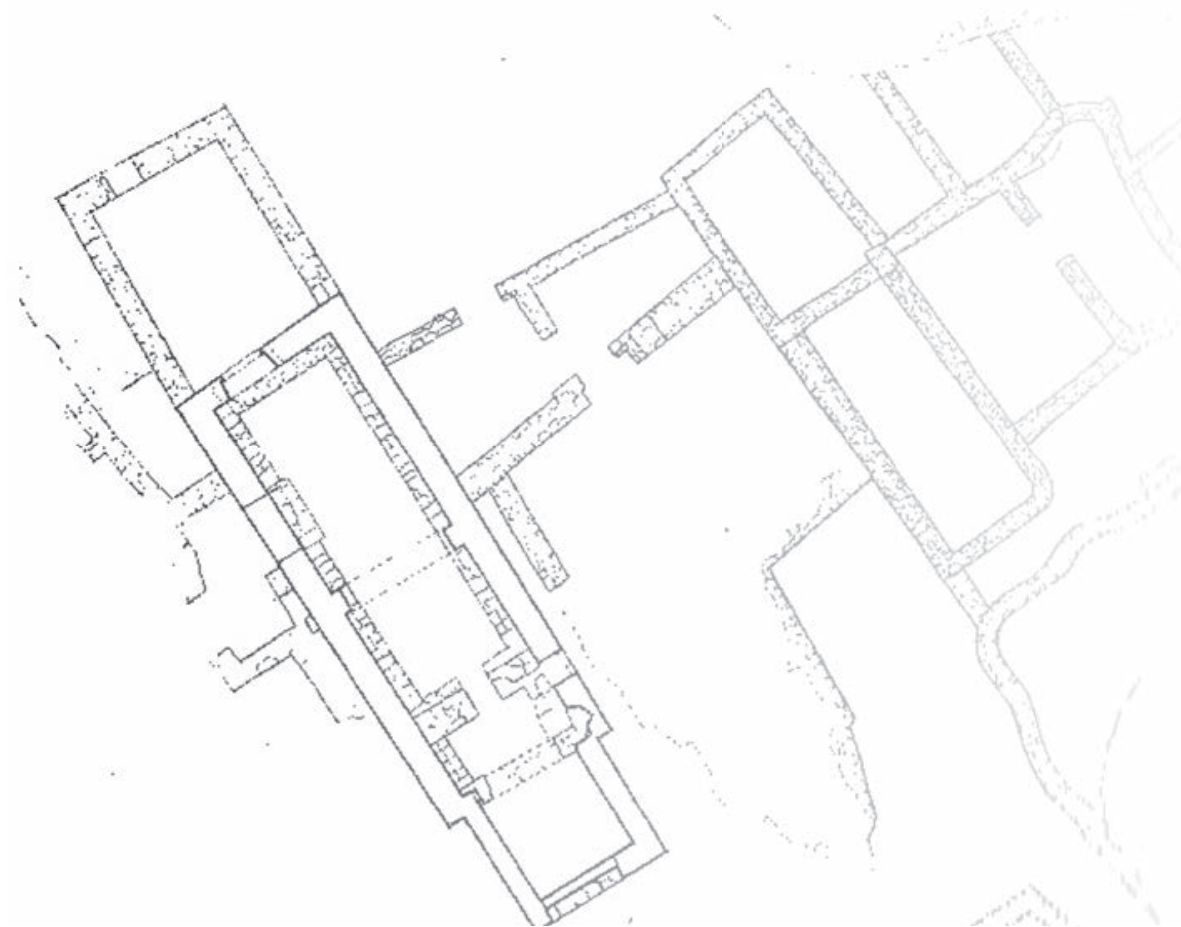

Fig. 24 S. Romà de Sidillà o de les Arenes (Girona), planta del conjunto, que primero fue interpretado como un poblado y posteriormente con un monasterio, según el Servicio de Patrimonio Arqueológico de la Generalitat de Cataluña, en G. BOTO VARELA, 2006. la Arqueología. Como recientemente ha vuelto a recordar López Quiroga, al día de hoy: "Es necesario subrayar que poco, realmente muy poco, es lo que el registro arqueológico ha permitido avanzar respecto a la visión normativa contenida en las reglas monásticas por diversas razones que se resumen en la inexistencia de una verdadera 'arqueología monástica' en la Península Ibérica”"142.

¿Por qué esta dificultad? Es más, ¿Sabríamos diferenciar -solo por la Arqueología- un hábitat monástico de un hábitat rural tipo vicus, o del tipo parrochia? Pues parece ser que no, que algunos se identificaron primero como poblados, como Sant Román de les Arenes 143 (fig. 24). Algo muy parecido sucedió con la identificación de villae y monasterios en la Antigüedad Tardía ${ }^{144}$. Pero, ¿Acaso los 'cenobios' no fueron durante estos siglos altomedievales un centro de producción más? En mi opinión, y ya que la ecclesia puede aparecer en ambos, lo que por el momento permitiría diferenciar una 'aldea espiritual' de una 'aldea laica' es la organización interna de su espacio, que en el primero giraría inequívocamente en torno a un edificio cultual, que será el punto de referencia de la localización de otras dependencias destinadas a actividades comunitarias: refectorio, dormitorio, etc. el resto de dependencias, especialmente las destinadas a actividades productivas (hornos, molinos, etc.,), en nada se diferenciarían, en su factura, de sus homónimas laicas, a no ser por su ubicación (fig. 25). Es decir, como ya señalé hace más de una década, apenas conocemos la organización del espacio monástico (cenobítico) altomedieval, que no de su función, que para nosotros resultaba más o menos clara: mientras que el cenobio en la Antigüedad Tardía, pero especialmente desde la segunda mitad del s. VI, fue utilizado como vehículo para la evangelización y cristianización del territorio (con la inclusión de baptisterios), en la Alta Edad Media hispana el monasterio se convierte en un espacio espiritual y productivo al servicio no de la cristianización o evangelización sino de la organización política y explotación del territorio. En ambos casos, como una fórmula más de control del espacio rural, del territorium.

Esperemos que las investigaciones que se tienen previsto llevar a cabo en los próximos meses en el monasterio leonés de San Pedro de Montes (el monasterium ruphianense), un monasterio fructuosiano de la primera mitad del s. VII restaurado y ampliado por San Genadio en los ss. IX-X (fig. 26) puedan arrojar algo de luz sobre la configuración material y ordenación espacial de los 'poblados o aldeas espirituales' de época tardoantigua y altomedieval en Hispania, tal y como lo están haciendo las investigaciones realizadas en monasterios carolingios de finales del s. VIII, como en el de Aniano ${ }^{145}$ o en las abadías italianas

${ }^{141}$ A.M. MARTÍNEZ TEJERA, op. cit. (n. 12), p. 68, n. 96.

${ }^{142}$ J. LÓPEZ QUIROGA, Monasterios altomedievales hispanos. Lugares de emplazamiento y ordenación de sus espacios, in Los monasterios medievales en sus emplazamientos: lugares de memoria de lo sagrado, Aguilar de Campoo, 2016, p. 65-99, especialmente p. 67-68.

${ }^{143}$ G. BOTO VARELA, op. cit. (n. 68), p. 76-77.

${ }^{144}$ J. ARCE, Las 'villae' romanas no son monasterios, in Archivo Español de Arqueología, 65, 165-166, Madrid, 1992, p. 323-330.

${ }^{145}$ L. SCHNEIDER, Aniane. Abbaye, in Bilan scientifique de la región Languedoc-Rousillon, Montpellier, 2014, p. 117-122. 


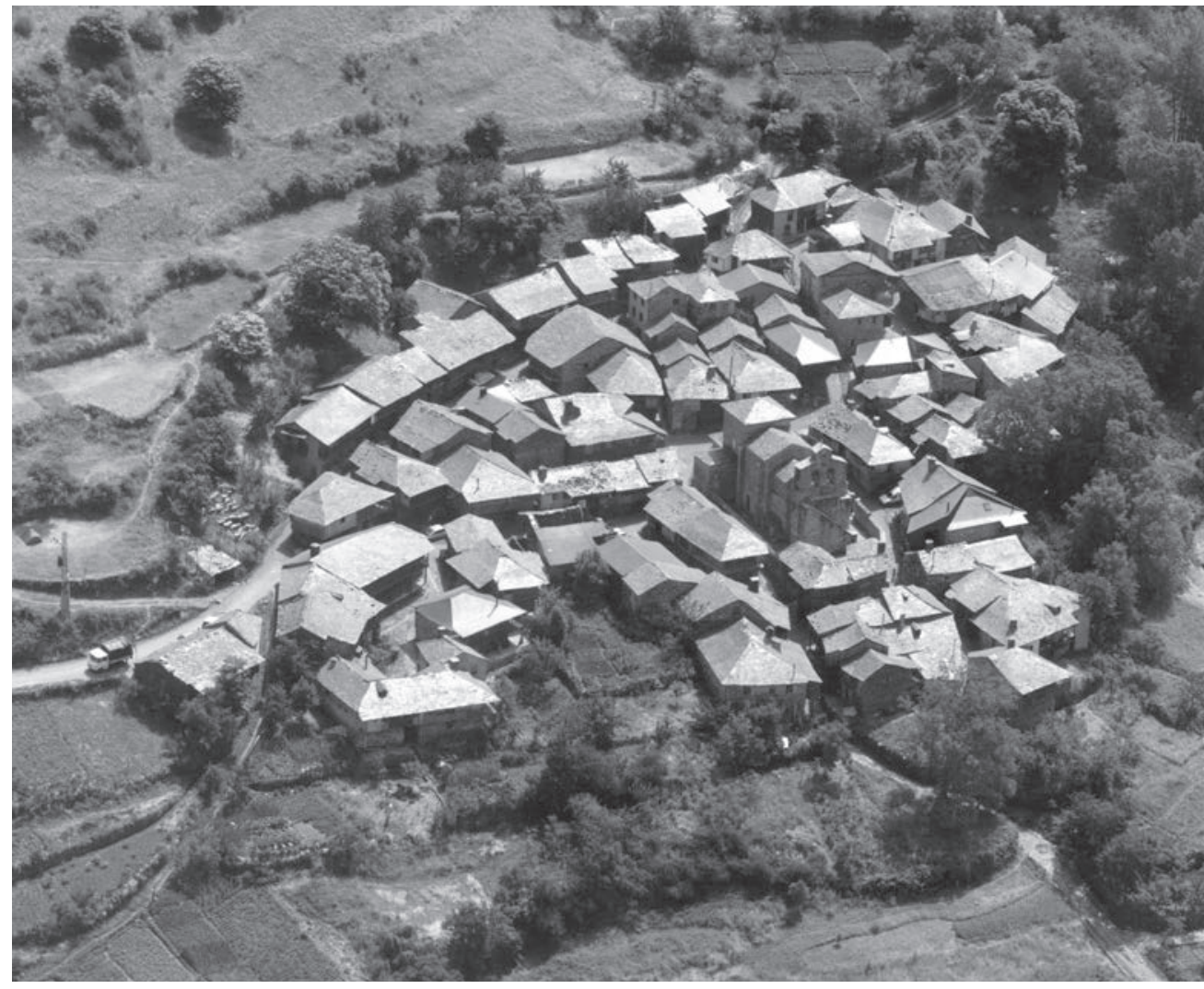

Fig. 25 Vista aérea de Peñalba de Santiago (León), cuyo monasterio fue fundado entre los años 909-920 aprox. y consagrado hacia el año 937 por el obispo Salomón: ¿dónde comienza el monasterio y termina la aldea? (C) Paisajes Españoles, Madrid).

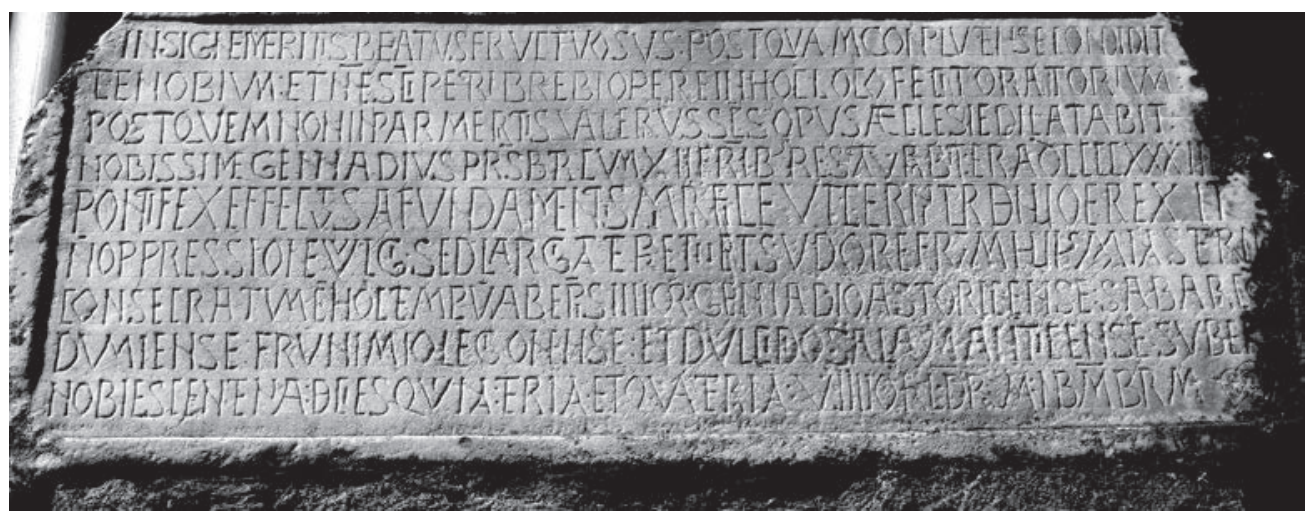

Fig. 26 Monumento de Consagración de la iglesia altomedieval de San Pedro de Montes; realizado después del año 940, cuenta la evolución del monasterio desde su fundación, en la primera mitad del s. VII, hasta el año 919, en el que cuatro obispos consagraron una nueva iglesia, la auspiciada por el obispo de Astorga, Iennadius (C) Ángela Crespo Espinel). de Nonantola ${ }^{146}$ y San Vincenzo ad Volturno $^{147}$, que están mostrando su evolución desde el s. VIII hasta el presente. Además, se va a analizar como fue su relación con el territorio en el que se implantó, que llegó a convertirse en una auténtica 'Thebaida', en un auténtico 'territorio monástico' entre los ss. VII-XI.

En España, por el momento, la utilización de la Arqueología para trazar las características organizativas y constructivas de los cenobios altomedievales apenas está dando frutos, tal vez, pensamos, por el hecho de que determinada 'tendencia arqueológica' se empeña en enfrentar el 'documento escrito' con el llamado 'documento excavado' ${ }^{148}$ cuando, en realidad, resultan complementarios. Yasí llevamos ya más de un cuarto de siglo, sin apenas haber evolucionado en nuestro conocimiento respecto a los datos ofrecidos por las fuentes escritas, por muy teóricas y abstractas que estas le resulten a algunos colegas ${ }^{149}$. Únicamente la conjunción de ambas puede dar algún fruto, y eso es lo que en nuestro caso venimos haciendo desde $1990^{150}$, cuando por vez primera desde la Historia del Arte nos aproximamos a la arquitectura monástica hispana tardoantigua y altomedieval a partir de las reglas monásticas y de los restos materiales con el fin de buscar algo más que un 'organigrama ideal' o 'teórico' del cenobio altomedieval hispano ${ }^{151}$. Desde la Historia y la Historia del Arte se han dado algunas pistas de como se organizaba y las dependencias con las que pudo llegar a contar. ¿Y desde la Arqueología? Sin excavaciones, muy difícilmente.

\footnotetext{
${ }^{46}$ S. GELICHI - M. LIBRENTI, Ricerche archaelogiche su una grande abbazia altomedievales: San Silvestro di Nonantola, in Monasteria et territoria, op. cit. (n. 1), p. 337-348.

${ }_{147}$ F. MARAZZI, San Vincenzo al Volturno. L'abbazia e il suo territorium fra VIII e XII secolo, Presentazione di F. Avagliano, Montecassino, 2012.

${ }^{148} \mathrm{~A}$ pesar de reconocer "la existencia de obras que, aunque con un carácter general, han demostrado la eficacia y las posibilidades de colaboración de ambas vías": F.J. MORENO MARTÍN, op. cit. (n. 1), p. 205 y nota no 25.

149 Ibidem, p. 207 y ss.

${ }^{150}$ Dos años después de que se publicara el primer estudio dedicado al espacio monástico hispano del s. VII desde la perspectiva arqueología: L. CABALLERO ZOREDA, Monasterios visigodos. Evidencias arqueológicas, in Codex Aquilarensis, 1, Aguilar de Campoo, Palencia, 1988, p. 31-50; A.M. MARTÍNEZ TEJERA, op. cit. (n. 8). Este último texto, aunque aparecido en 1997, fue enviado para su publicación en 1990.

${ }^{151}$ En ningún momento el investigador puede perder de vista que la regla, la teoría, se redacta con el fin de ser observada y obedecida. Conocer hasta que punto fue llevada a la práctica es la asignatura pendiente de la Arqueología, su "revolución metodológica". Para nosotros, como Historiadores del Arte, no nos cabe la menor duda de que las reglas monásticas condicionan la topografía monástica, pues así lo indican en infinidad de ocasiones.
} 